PRELIMINARY INTERPRETIVE REPORT 2014-3

\title{
GEOLOGIC-MAPPING-BASED OBSERVATIONS \\ OF THE MIDDLE JURASSIC CHINITNA FORMATION AND \\ UPPER JURASSIC NAKNEK FORMATION IN THE TILTED HILLS, INISKIN PENINSULA, COOK INLET, ALASKA
}

by

Trystan M. Herriott and Marwan A. Wartes

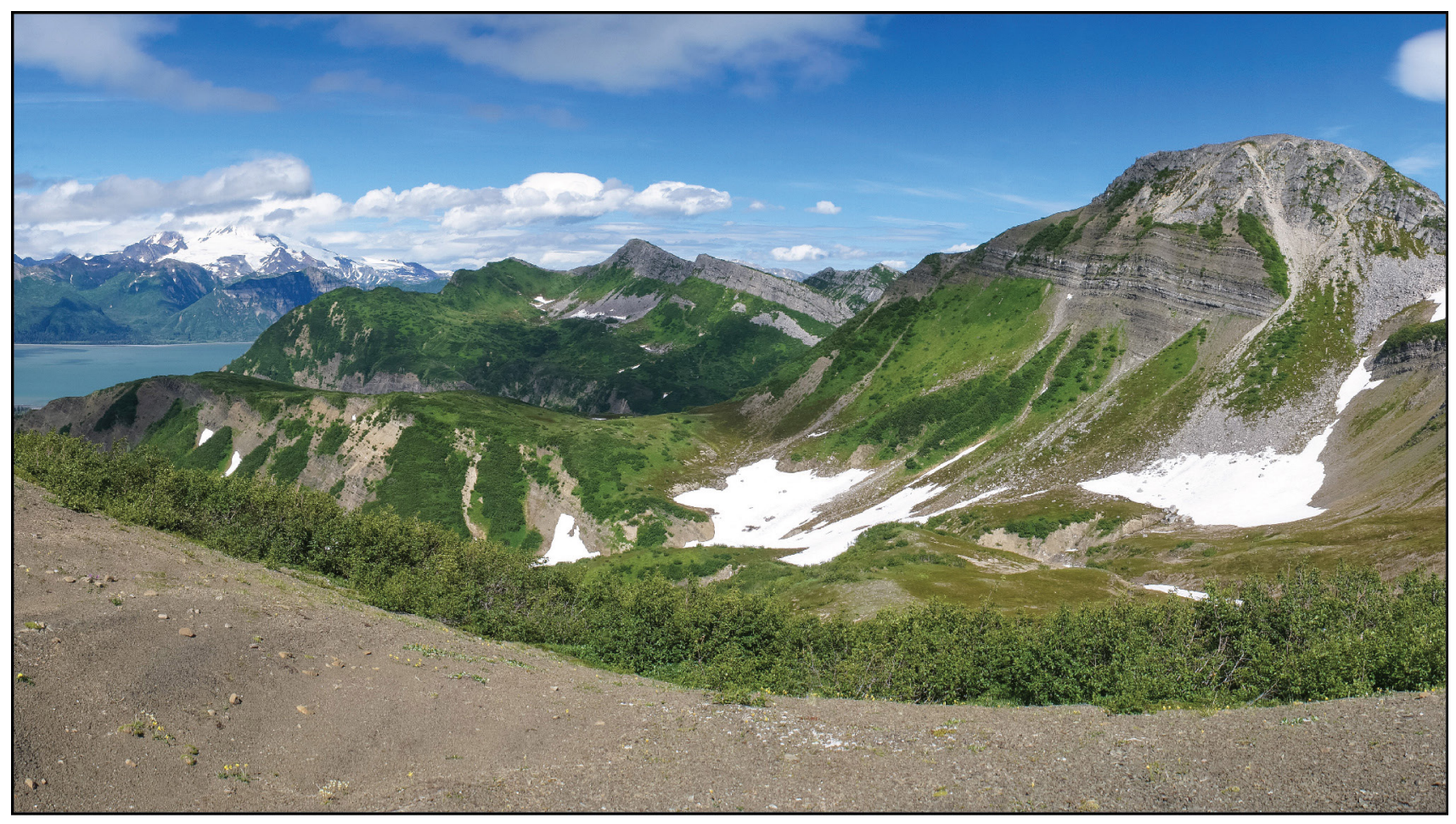

View northeastward of the Tilted Hills near Mount Chinitna, with Chinitna Bay and snow- and ice-clad Iliamna Volcano $(10,016$ feet) at left of photograph. The Middle and Late Jurassic Chinitna and Naknek Formations crop out extensively in this physiographically prominent, northeast-trending outcrop belt on the Iniskin Peninsula. The broad, gray-weathering peak at right of the photograph comprises Pomeroy Arkose Member (Naknek Formation), with dark-gray-weathering Snug Harbor Siltstone Member (Naknek Formation) strata cropping out along the skyline left of the peak. Lower sandstone member (Naknek Formation) and Chinitna Formation lie left of the snowfield and saddle (center of photograph). Photograph by T.M. Herriott.

June 2014

Released by

STATE OF ALASKA

DEPARTMENT OF NATURAL RESOURCES

Division of Geological \& Geophysical Surveys 



\section{CONTENTS}

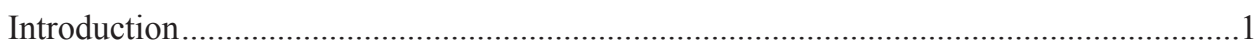

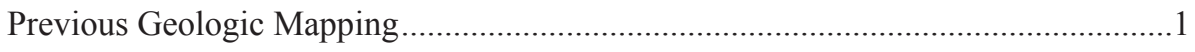

2013 Geologic Mapping in the Tilted Hills........................................................... 1

Discussion of Map Units and Mapping-Based Observations ...........................................

Chinitna Formation (Middle Jurassic)...........................................................

Tonnie Siltstone Member (Bathonian and Callovian)......................................

Paveloff Siltstone Member (Callovian) .............................................................

Naknek Formation (Upper Jurassic) ...............................................................

Chisik Conglomerate Member (Oxfordian) .................................................... 7

Lower Sandstone Member (informal) (Oxfordian).......................................11

Snug Harbor Siltstone Member (Oxfordian to Kimmeridgian[?]).....................12

Pomeroy Arkose Member (Kimmeridgian) .................................................. 17

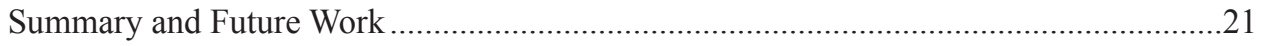

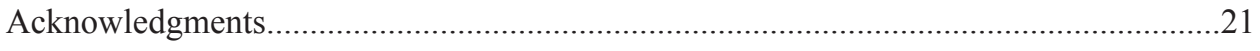

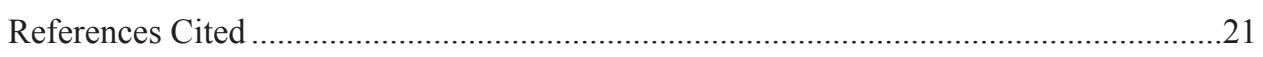

\section{FIGURES}

Figure 1. Index map of the Iniskin Peninsula area ................................................2

2. Simplified geologic map of the Tilted Hills, Iniskin Peninsula, including the Chinitna and Naknek Formations, as well as the underlying Bowser Formation (Tuxedni Group)...

3. Oblique aerial view eastward of Chinitna and Naknek Formations exposed in the cliff faces and cuestas characteristic of the Iniskin Peninsula's Tilted Hills

4. Oblique aerial view southeastward of an unnamed mountain northeast of Front Mountain, portraying mappable characteristics of the Tonnie Siltstone Member (Jct) and associated map unit contacts

5. Photographs exhibiting outcrop and lithologic characteristics of the Tonnie Siltstone Member, Chinitna Formation.

6. Oblique aerial view eastward of Front Mountain, portraying mappable characteristics of the Paveloff Siltstone Member (Jcp) and associated map unit contacts

7. Photographs exhibiting outcrop and lithologic characteristics of the Paveloff Siltstone Member, Chinitna Formation .8

8. Oblique aerial view southwestward of the Mount Pomeroy area, portraying mappable characteristics of the Naknek Formation members and associated map unit contacts

9. Oblique aerial photographs portraying mappable characteristics of the Chisik Conglomerate Member (Jnc) and associated map unit contacts along the east shore of Iniskin Bay.

10. Photographs exhibiting outcrop and lithologic characteristics of the Chisik Conglomerate Member, Naknek Formation. 
11. Photographs portraying mappable characteristics of the lower sandstone member and associated map unit contacts.

12. Photographs exhibiting outcrop and lithologic characteristics of the lower sandstone member, Naknek Formation

13. Photograph portraying mappable characteristics of the Snug Harbor (Jns)Pomeroy (Jnp) contact .................................................................................. 16

14. View eastward of Mount Pomeroy, with exposure of Snug Harbor Siltstone Member on the peak's northern flanks

15. Photographs exhibiting outcrop and lithologic characteristics of the Snug Harbor Siltstone Member, Naknek Formation.

16. View northeastward of a ridge west of Griffin Creek with characteristic weathering profile of the Snug Harbor Siltstone Member (Jns) in the Tilted Hills area.

17. Photographs exhibiting outcrop and lithologic characteristics of the Pomeroy Arkose Member, Naknek Formation . 


\title{
GEOLOGIC-MAPPING-BASED OBSERVATIONS \\ OF THE MIDDLE JURASSIC CHINITNA FORMATION AND UPPER JURASSIC NAKNEK FORMATION IN THE TILTED HILLS, INISKIN PENINSULA, COOK INLET, ALASKA
}

\author{
by \\ Trystan M. Herriott ${ }^{1}$ and Marwan A. Wartes ${ }^{1}$
}

\section{INTRODUCTION}

During field seasons in 2009, 2010, 2012, and 2013, the Alaska Division of Geological \& Geophysical Surveys (DGGS), in collaboration with the Alaska Division of Oil \& Gas (DOG) and U.S. Geological Survey (USGS), conducted geologic field investigations on the Iniskin Peninsula and surrounding areas of lower Cook Inlet, south-central Alaska (fig. 1; Gillis [ed.], 2013, 2014). The Cook Inlet forearc basin hosts a prolific petroleum system that yields gas and oil from dominantly Tertiary-age nonmarine sandstone and conglomerate reservoirs (Magoon, 1994; LePain and others, 2013), with the oil thought to be sourced from organic-rich shales in the Middle Jurassic Tuxedni Group (Magoon and Anders, 1992; Lillis and Stanley, 2011; LePain and others, 2013). Our recent work in Cook Inlet has focused chiefly on the Middle and Upper Jurassic stratigraphy (LePain and others, 2011; Wartes and others, 2011, 2013; Stanley and others, 2013), as well as the structure of the basin's northwest, magmatic arc-proximal margin (Betka and Gillis, 2014; Betka and Gillis, in press); Gillis and others, 2011, 2013; LePain and others, 2011; Wartes and others, 2011,2013). This report documents the distribution of mappable members in the Tilted Hills (fig. 1) and aims to improve our understanding of depositional systems recorded in the Jurassic stratigraphy of the Cook Inlet forearc basin, including key parameters such as accommodation and sediment supply, as well as the nature and timing of deformation. Ultimately, this and related investigations will bolster our understanding of the stratigraphic, structural, and tectonic evolution of the basin and shed additional light on source-rock characteristics and reservoir potential of Mesozoic strata in Cook Inlet.

\section{PREVIOUS GEOLOGIC MAPPING}

The Iniskin Peninsula has long been a focus of geologic studies, with much of the initial work dating to the early 20th century (Martin, 1905; Stanton and Martin, 1905; Martin and Katz, 1912). These pioneering studies were largely motivated by known occurrences of oil and gas seeps in Middle to Upper Jurassic strata (Detterman and Hartsock, 1966; Blasko, 1976). First-order geologic mapping on the Iniskin Peninsula was completed by Moffit (1927; 1:62,500 scale), with additional detailed mapping by Kirschner and Minard (1949; 1:48,000 scale) and Hartsock (1954; 1:40,000 scale). R.L. Detterman compiled the seminal report on the Iniskin Peninsula and surrounding areas, including a 1:63,360-scale geologic map (Detterman and Hartsock, 1966). Detterman and Hartsock's 1966 paper and map are based on several field campaigns by U.S. Geological Survey geologists during the late 1940s and early 1950s, as well as two additional field seasons by Detterman in 1957 and 1958. Regional 1:250,000-scale geologic maps that encompass the Iniskin Peninsula and surrounding areas include those by Magoon and others (1976), Detterman and Reed (1980), and Wilson and others (2012).

\section{GEOLOGIC MAPPING IN THE TILTED HILLS}

DGGS and DOG geologists conducted helicopter-supported geologic mapping of the Iniskin Peninsula during the 2013 field season (see project overview in Gillis [ed.], 2014; Gillis and others, 2014), with the authors of this report focusing on the bedrock geology of the Tilted Hills (fig. 2). The Tilted Hills extend for approximately $30 \mathrm{~km}$ along the southeastern Iniskin Peninsula and constitute a physiographically prominent, chiefly northeast-trending belt of peaks, ridges, and areally extensive flatirons (fig. 3). Outcrops in the map area dominantly consist of the Chinitna and Naknek Formations, permitting examination of latest Middle and Upper Jurassic forearc basin strata of Cook Inlet (fig. 2). These Jurassic strata are generally southeast dipping, decreasing in age from northwest to southeast. An overview of our mapping-based field observations is provided below as a more thorough treatment of this work than is provided by Herriott and Wartes (2014).

\section{DISCUSSION OF MAP UNITS AND MAPPING-BASED OBSERVATIONS}

\section{CHINITNA FORMATION (MIDDLE JURASSIC)}

The Tonnie Siltstone and Paveloff Siltstone Members (Detterman and Hartsock, 1966) are the lower and upper units, respectively, of the Chinitna Formation (Imlay, 1953; Hartsock, 1954; Detterman and Hartsock, 1966; fig. 2), which has also been variously referred to as the Chinitna Shale (Stanton and Martin, 1905; Martin and Katz, 1912; Moffit, 1927)

${ }^{1}$ Alaska Division of Geological \& Geophysical Surveys, 3354 College Rd., Fairbanks, Alaska 99709-3707; trystan.herriott@alaska.gov 


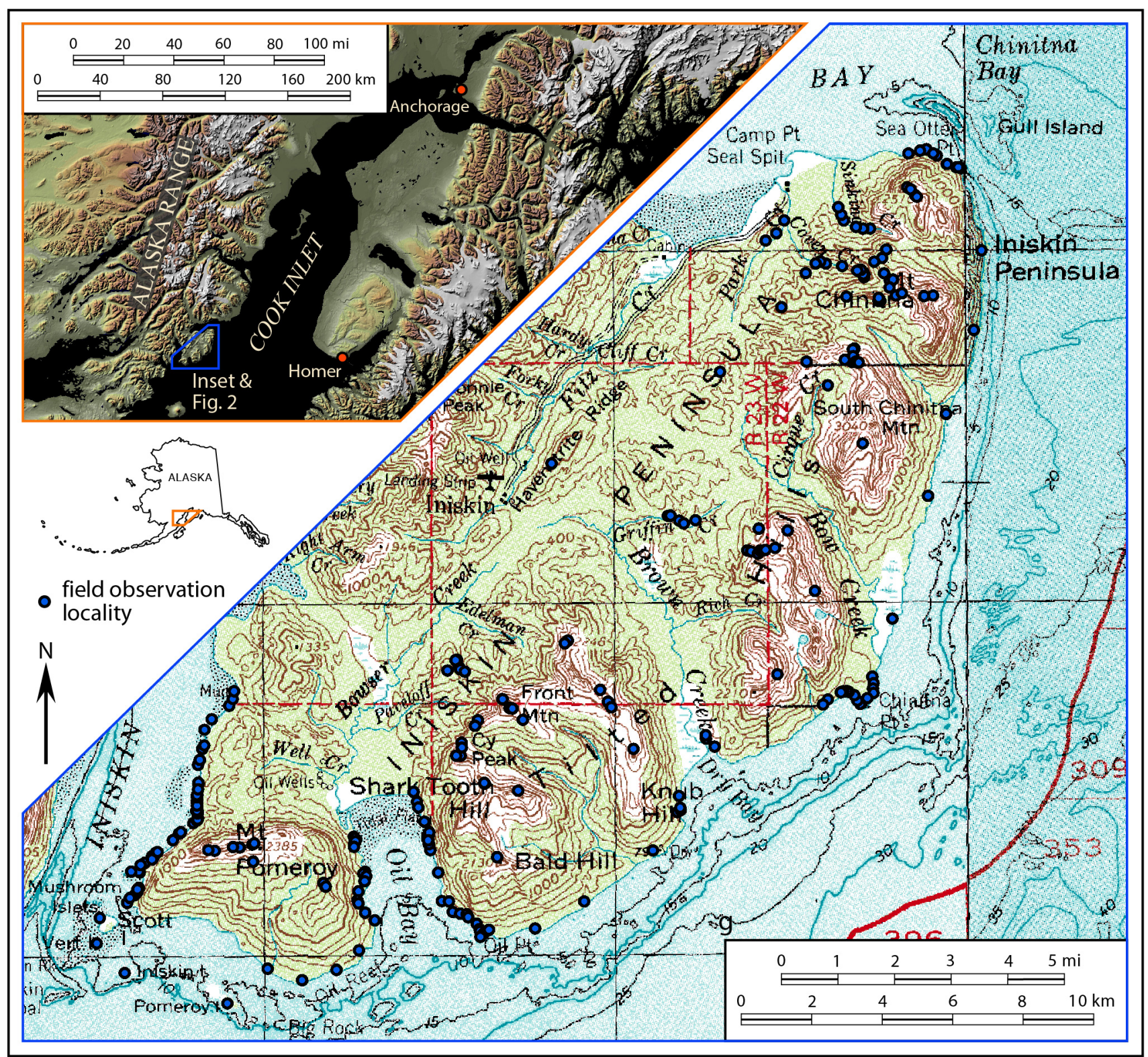

Figure 1. Index map of the Iniskin Peninsula area. Detailed observations were made at more than 300 localities during four field seasons in the area. Topographic base map from portions of U.S. Geological Survey Iliamna and Seldovia 1:250,000-scale quadrangles; shaded-relief image modified after U.S. Geological Survey Elevation Data Set Shaded Relief of Alaska poster (http://eros.usgs.gov/alaska-0).

and Chinitna Siltstone (Kirschner and Minard, 1949). The member designations of the Chinitna have previously varied widely (Kirschner and Minard, 1949; Imlay, 1953; Detterman and Hartsock, 1966), but we regard the two-part subdivision of Detterman and Hartsock (1966) to be recognizable in most field exposures and our mapping follows their stratigraphic nomenclature. Biostratigraphic work on the Chinitna Formation ammonite collections by Imlay (1953, 1975; see also Detterman and Hartsock, 1966) indicated a Callovian ${ }^{2}$ age for the unit, although the basal Tonnie was later recognized to include upper Bathonian strata (Imlay, 1981a; Callomon, 1984). Imlay (1953) subdivided the Chinitna into three parts, with Detterman and Hartsock (1966) reporting Imlay's lower two-thirds and upper one-third of the unit are approximately equivalent to the Tonnie and Paveloff, respectively (see also Imlay, 1975).

\footnotetext{
${ }^{2}$ The Callovian was formerly included as the first stage of the Late Jurassic epoch, but is now recognized as the final stage of the Middle Jurassic epoch (Maubeuge, 1964; Gradstein and others, 2012). Imlay (1953) and Detterman and Hartsock (1966) considered the Chinitna Formation to be entirely Upper Jurassic, based on the Callovian fauna (later recognized to include the upper Bathonian) and existing chronostratigraphic nomenclature.
} 


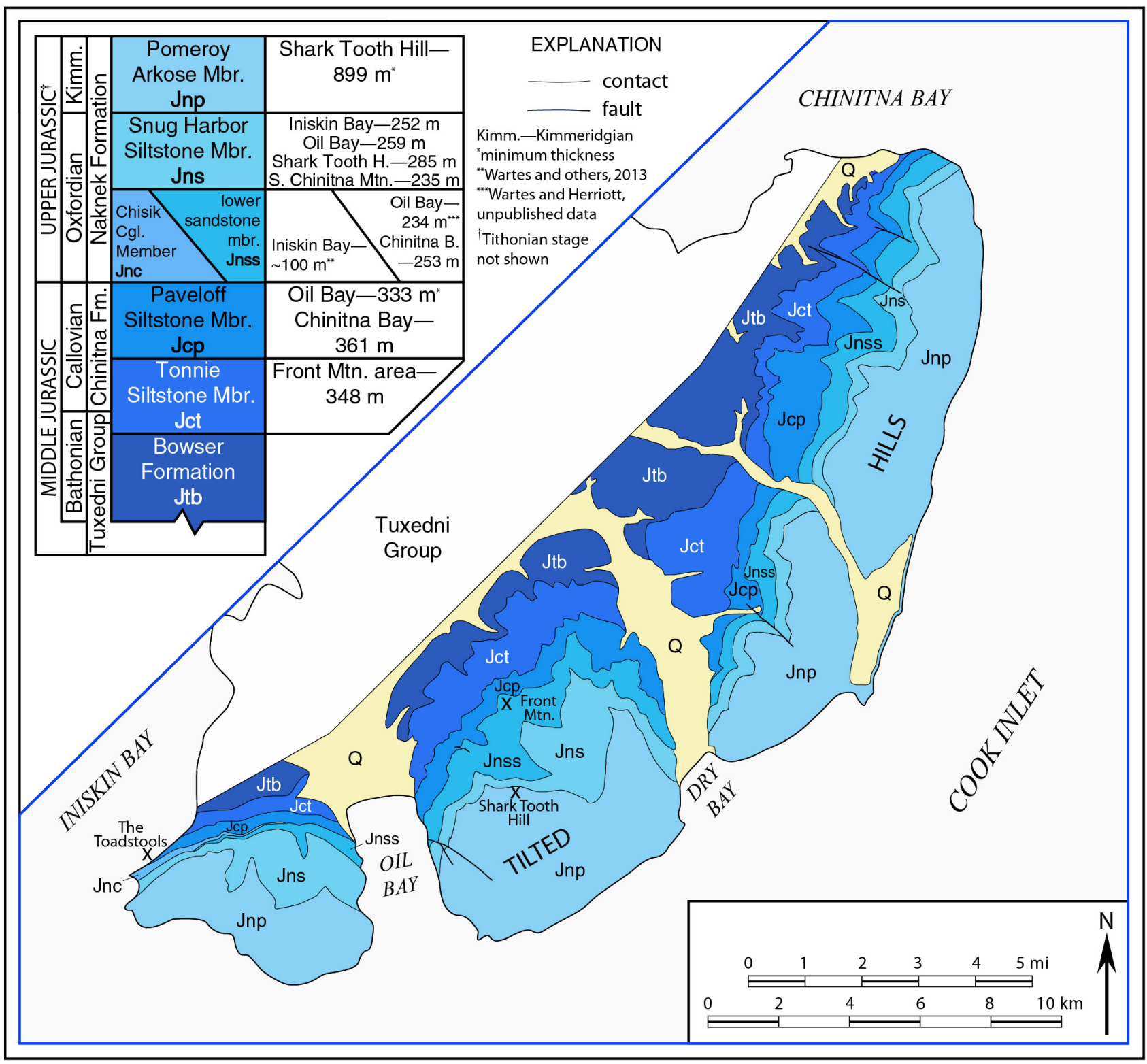

Figure 2. Simplified geologic map of the Tilted Hills, Iniskin Peninsula, including the Chinitna and Naknek Formations, as well as the underlying Bowser Formation (Tuxedni Group). This preliminary sketch map is based on 1:63,360-scale mapping completed during the 2013 field season and is part of a larger project focused on mapping the entire Iniskin Peninsula (see overview by Gillis [ed.], 2014; Gillis and others, 2014). Schematic stratigraphic column (modified after Detterman and Hartsock [1966]) is not scaled to time or thickness, nor does it reflect known depositional hiatuses. Reported stratigraphic thicknesses are from this study unless otherwise noted. See figure 1 for location index map.

The Chinitna Formation has been interpreted to consist of two depositional cycles in a marine shelf setting of the latest Middle Jurassic Cook Inlet forearc basin, with each cycle exhibiting regressive, coarser-grained basal deposits that transition into overlying transgressive, finer-grained, dominantly siltstone packages (LePain and others, 2013). These two cycles are recognized as the Tonnie Siltstone (lower cycle) and Paveloff Siltstone (upper cycle) Members.

\section{Tonnie Siltstone Member (Bathonian and Callovian)}

The Tonnie Siltstone Member occupies the northwesternmost exposures of the units discussed in this paper and generally lies near the base of prominent, northwest-facing escarpments in the Tilted Hills. Although mountain-scale exposures of the Chinitna Formation are common, they are generally inaccessible due to steep terrain and/or exceedingly dense brush cover. Furthermore, the Tonnie is chiefly siltstone-rich and recessive, typically yielding poor-quality exposures covered with vegetation or slope wash. However, many tens of meters of the member crop out in a sea cliff along the east shore of 


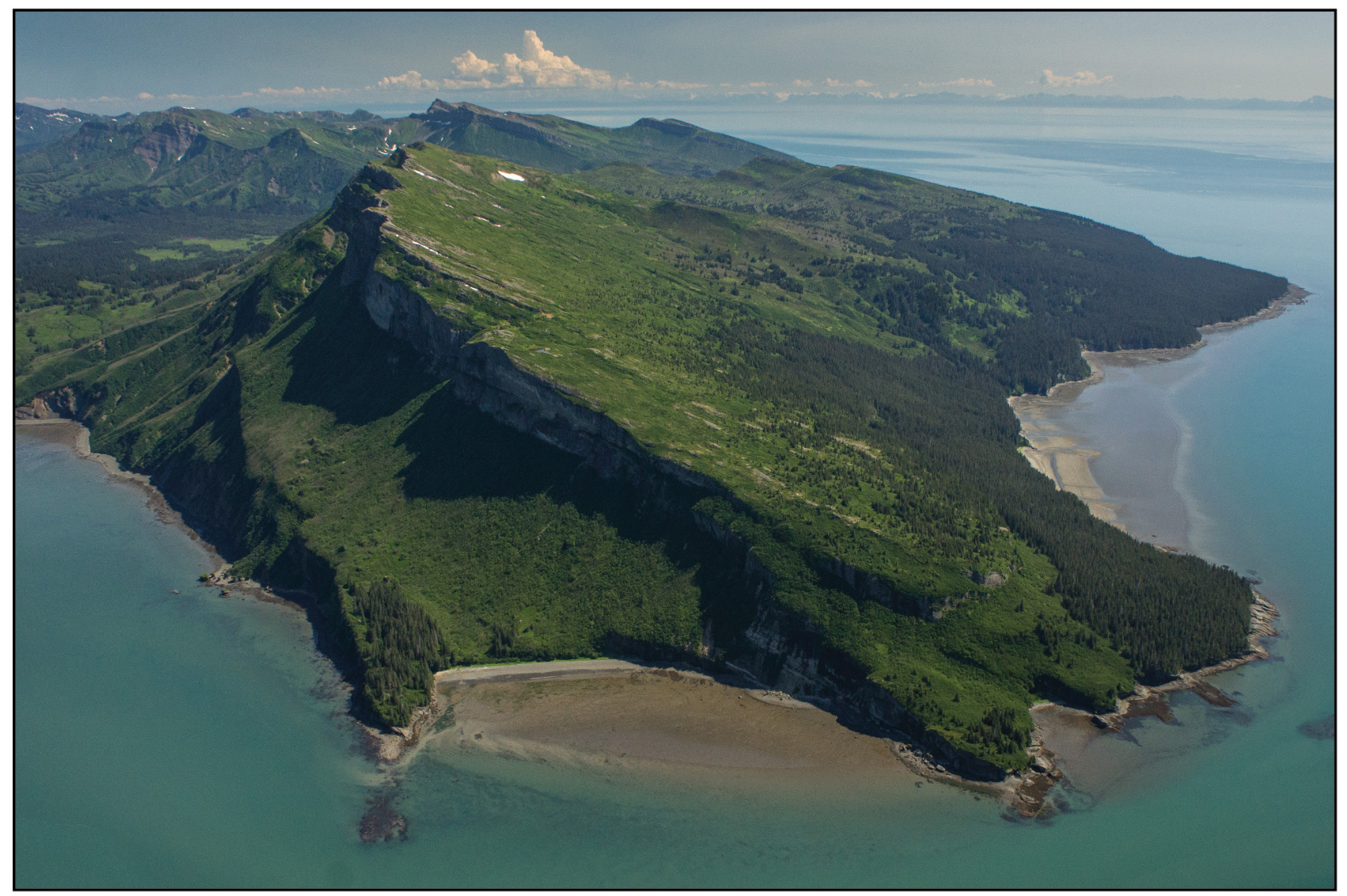

Figure 3. Oblique aerial view eastward of Chinitna and Naknek Formations exposed in the cliff faces and cuestas that are characteristic of the Iniskin Peninsula's Tilted Hills, with the east shore of Iniskin Bay in the foreground. The largest flatirons (for example, center of photograph) are present in the Pomeroy Arkose Member. Jurassic strata of the Tilted Hills dip southeastward into Cook Inlet, where they have been penetrated by exploration wells in Federal waters. The cove at lower center of photograph is $\sim 1 \mathrm{~km}$ wide, for sense of scale. Photograph by T.M. Herriott.

Iniskin Bay (fig. 1) northeast of The Toadstools (fig. 2). Discontinuous exposures of the uppermost Tonnie also occur on the south shore of Chinitna Bay (fig. 1), but these outcrops are only notable in their ease of access and not in the quality or continuity of exposure. Detterman and Hartsock (1966) reported that good exposures of this unit occur along the axis of Tonnie syncline to the northwest of the Tilted Hills, including the type section near Tonnie Peak.

The base of the Tonnie is typically covered by vegetation but is readily mappable in the Edelman and Paveloff creeks area near Front Mountain (fig. 1), where a resistant, light-gray-weathering package of uppermost Bowser Formation forms a laterally persistent bench that extends approximately $5 \mathrm{~km}$ along strike. Similar but typically less well expressed, lightgray-weathering beds are elsewhere employed to map the Bowser-Tonnie contact.

The commonly medium-brown-weathering color of the Tonnie contrasts well with the dark-gray-brown- to gray-greenweathering color of the overlying Paveloff Member (fig. 4). This weathering color change is commonly coincident with a mappable break-in slope: gentler gradient topography of the Tonnie yields upsection to steeper gradient slopes of the Paveloff (fig. 4).

The Tonnie dominantly comprises thin- to thick-bedded siltstone and sandy siltstone, with subordinate, thin-bedded, tabular, sharp-based sandstone (fig. 5A-C). Discrete trace fossils (fig. 5D) and probable thorough bioturbation are common in the unit. Calcareous concretionary horizons are pervasive in most exposures of the Tonnie, and individual concretions that define these horizons are commonly ellipsoidal to tabular and 10-20 cm thick (fig. 5B); this contrasts locally with concretionary horizons in the Paveloff Siltstone Member, which are similarly thick to somewhat thicker and more commonly tabular. A map-scale thickness calculation ${ }^{3}$ for the Tonnie Siltstone Member in the Edelman-Paveloff creeks area yielded an estimated stratigraphic thickness of $348 \mathrm{~m}$ (fig. 2).

\footnotetext{
${ }^{3}$ The method employed is largely akin to the tape-compass-clinometer technique of Compton (1985; p. 234-235), but is dependent on precise latitude and longitude coordinates of observed contacts rather than a tape measure.
} 


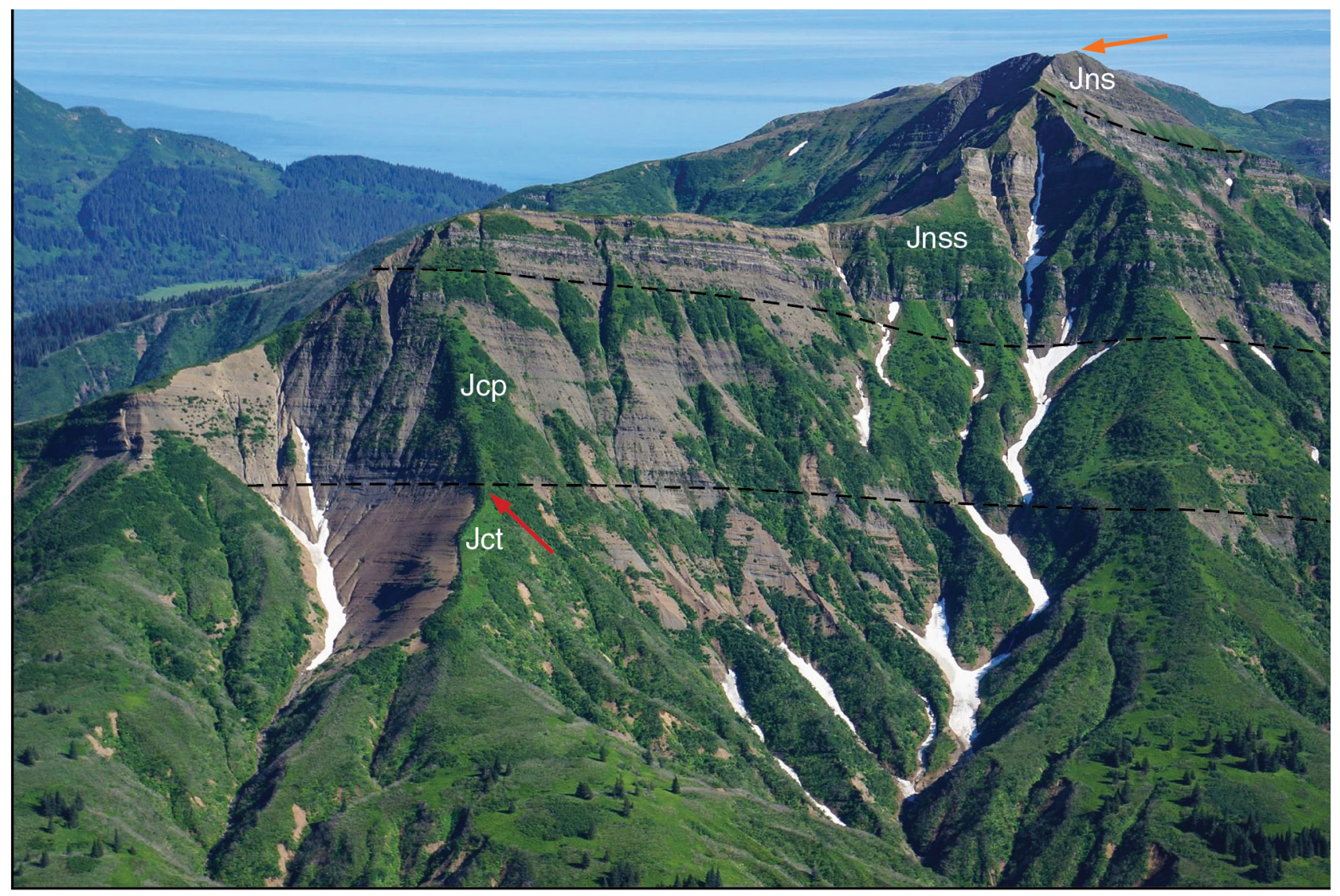

Figure 4. Oblique aerial view southeastward of an unnamed mountain northeast of Front Mountain, portraying mappable characteristics of the Tonnie Siltstone Member (Jct) and associated map unit contacts. The medium-brown-weathering color of Tonnie contrasts well against the dark-gray-brown-weathering color of the overlying Paveloff Siltstone Member (Jcp). Additionally, the Tonnie-Paveloff weathering color change is commonly coincident with a mappable break-in slope (red arrow). Note also the striped color character of part of the lower sandstone member (Jnss), and that the Snug Harbor Siltstone Member (Jns) comprises the mountain's summit (orange arrow). For sense of scale, the Paveloff is typically $>300 \mathrm{~m}$ thick in the study area. Photograph by M.A. Wartes.

\section{Paveloff Siltstone Member (Callovian)}

The Paveloff Siltstone Member commonly crops out within laterally persistent, northwest-facing escarpments in the Tilted Hills, immediately underlying ridges and peaks of the Naknek Formation. As is typically the case with the underlying Tonnie, Paveloff exposures in the high country are largely inaccessible due to steep topography, dense brush cover, or both. However, excellent, traversable outcrops of nearly completely exposed Paveloff are present along the east shore of Oil Bay (fig. 1) and south shore of Chinitna Bay. We also examined a similarly excellent section of the uppermost approximately $100 \mathrm{~m}$ of the Paveloff on Oil Bay's west shore, and discontinuous but notable outcrops also occur along Iniskin Bay.

The base of the Paveloff is locally well exposed, lying at the break-in-slope (gentle slope in the Tonnie and moderate slope in the Paveloff) and color change (medium-brown-weathering Tonnie and dark-gray-brown- and gray-green-weathering Paveloff; fig. 4). The top of the Paveloff is mapped at the contact with the overlying, chiefly coarser-grained lower sandstone member (Naknek Formation; informal subdivision) that is commonly more resistant to erosion. In mountain-scale exposures, however, the Paveloff-lower sandstone contact can be enigmatic where the basal lower sandstone strata do not exhibit the unit's characteristic striped color scheme of alternating medium-brown- and light-gray-weathering beds (fig. 6). In these areas, a contact must be correlated to nearby accessible outcrops where detailed observations of lithofacies, fresh color, and composition can be made: the Paveloff is typically more silt-rich, thinner bedded (although primary bedding thickness is commonly obscured in the Paveloff due to probable thorough bioturbation), greener colored, and less arkosic. In the Iniskin Bay-Mount Pomeroy area (fig. 1), the Paveloff is directly overlain by the lithologically conspicuous Chisik Conglomerate Member of the Naknek Formation.

The Paveloff dominantly comprises thin- to thick-bedded, lithic-rich, sandy siltstone, with subordinate, thin-bedded, very-fine-grained sandstone (fig. 7A). However, we locally observed a very-thick-bedded, basal sand-rich package greater than $100 \mathrm{~m}$ thick in the Paveloff that is best expressed along the south shore of Chinitna Bay (fig. 7B); an oil-stained 

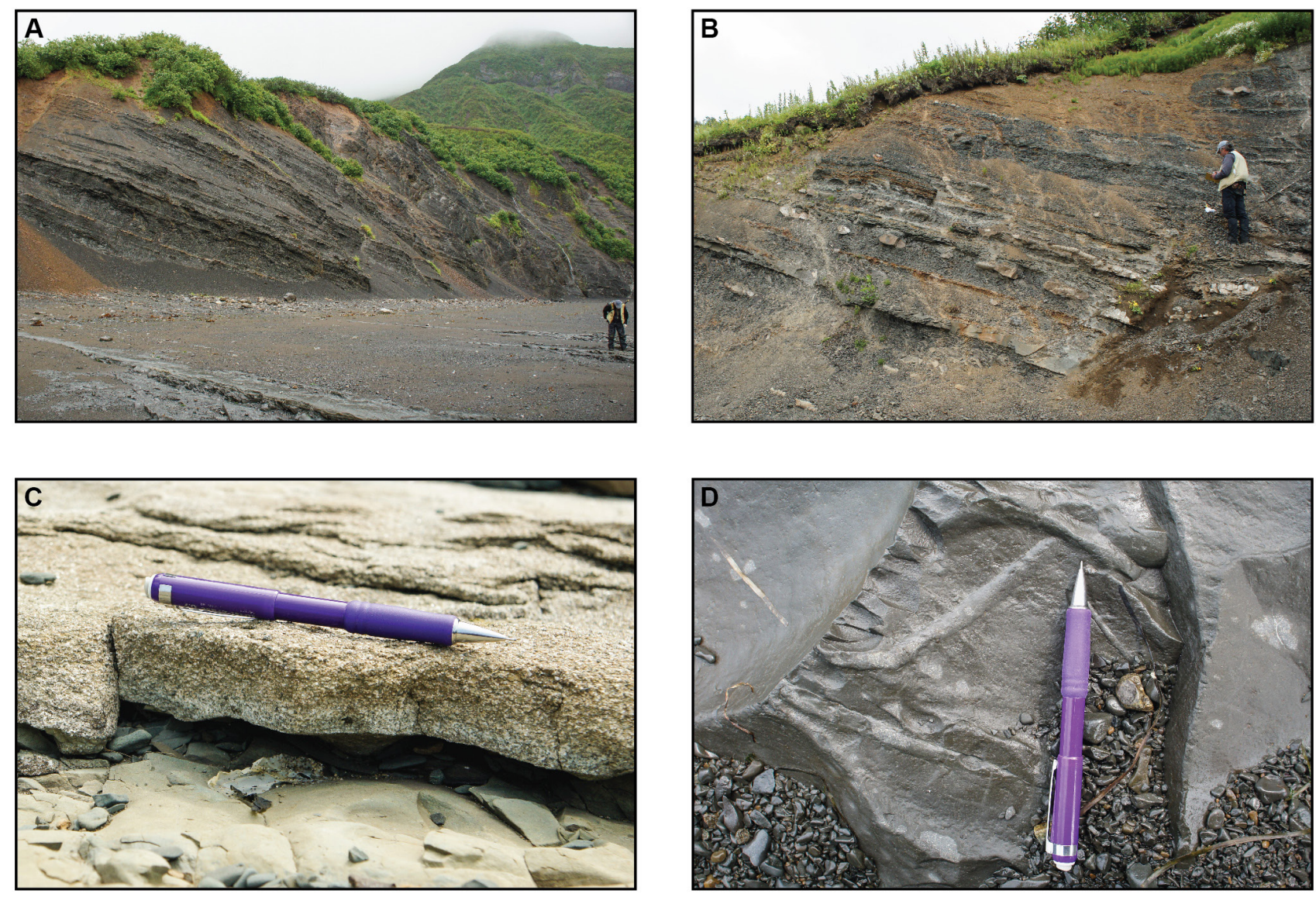

Figure 5. Photographs exhibiting outcrop and lithologic characteristics of the Tonnie Siltstone Member, Chinitna Formation. (A) Siltstone and sandstone beds along the east shore of Iniskin Bay. Geologist for scale. (B) Thin-to medium-bedded strata, with ellipsoidal and tabular calcareous concretions. Geologist for scale. (C) Very-thin-bedded, sharp-based, coarse-grained sandstone. Pencil is $14 \mathrm{~cm}$ long. (D) Bedding-parallel trace fossils (Planolites[?]) in texturally structureless sandstone. Pencil is $14 \mathrm{~cm}$ long. Photographs by T.M. Herriott.

sandstone was discovered in the Paveloff at this Chinitna Bay locality (Wartes and Herriott, 2014; Wartes and Herriott, in press). Discrete trace fossils (fig. 7C and D) and probable thorough bioturbation are common in the unit, the latter yielding apparently very thick, texturally structureless beds (fig. 7A and E). Paveloff strata are chiefly gray-green on weathered and freshly broken surfaces (fig. 7) and typically disaggregate along fractures with centimeter-scale spacing to form small blocks in talus aprons (fig. 7D and F). Calcareous concretionary horizons are pervasive in most exposures of the Paveloff, and individual concretions that define these horizons are commonly tabular to ellipsoidal and 10-20+ cm thick (fig. 7F); this contrasts locally with concretionary horizons in the Tonnie Siltstone Member, which are somewhat thinner on average and more commonly ellipsoidal. Map-scale thickness calculations for the Paveloff Siltstone Member along the east shore of Oil Bay and south shore of Chinitna Bay yielded estimated stratigraphic thicknesses of $333 \mathrm{~m}$ (minimum) and $361 \mathrm{~m}$, respectively (fig. 2). The Oil Bay minimum thickness estimate for the Paveloff is likely close to the complete thickness, but the base of the unit is covered at this location.

\section{NAKNEK FORMATION (UPPER JURASSIC)}

The Naknek (Spurr, 1900) Formation has long been recognized to crop out along the Alaska Peninsula, with a discontinuous outcrop belt that extends for greater than $1,000 \mathrm{~km}$ northeastward through Cook Inlet and into the Talkeetna Mountains (for example, Wilson and others, 1998, 2012). In the Iniskin Peninsula area the Naknek Formation (Martin, 1905; Martin and Katz, 1912) has been variously subdivided into mappable members (Moffit, 1927; Kirschner and Minard, 1949; Hartsock, 1954; Detterman and Hartsock, 1966). Detterman and Hartsock (1966) mapped four Naknek members: the Chisik Conglomerate, lower sandstone (informal), Snug Harbor Siltstone, and Pomeroy Arkose. We recognize and retain Detterman and Hartsock's (1966) member designations, including the lower sandstone that they considered to be only of local significance and thus not warranting a formal member designation. Biostratigraphic age constraints indicate the following: the Chisik and lower sandstone are Oxfordian age (Detterman and Hartsock, 1966; Detterman and others, 1996); 


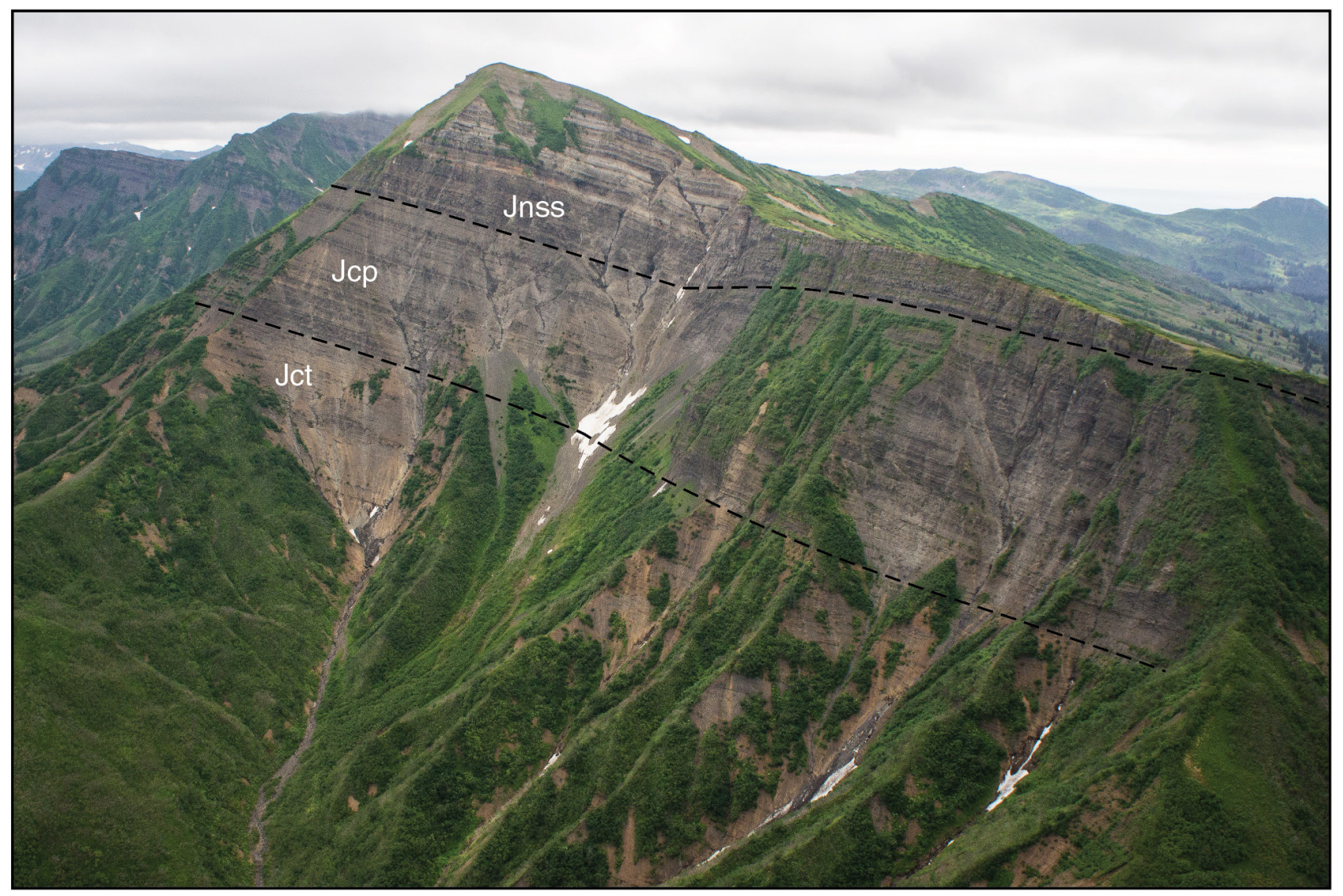

Figure 6. Oblique aerial view eastward of Front Mountain, portraying mappable characteristics of the Paveloff Siltstone Member (Jcp) and associated map unit contacts. Note strata that crop out at and immediately below the summit of Front Mountain have the striped color character common to the lower sandstone member (Jnss), but the lowermost section in the unit is simply dark-gray-brown weathering; only through examination of a nearby exposure north of Cy Peak did we observe the necessary lithofacies, weathering color, and sediment composition details to consistently map the Paveloff-lower sandstone contact across the face of Front Mountain (see text). Note also the color and topographic gradient changes at the Tonnie (Jct)-Paveloff contact. Paveloff is typically $>300 \mathrm{~m}$ thick in the study area, for sense of scale. Photograph by T.M. Herriott.

the Snug Harbor is Oxfordian to Kimmeridgian(?) age (Detterman and Hartsock, 1966; Imlay, 1981b); and the Pomeroy Arkose is Kimmeridgian age (Detterman and Hartsock, 1966; Imlay, 1981b).

The Naknek Formation records continued Cook Inlet forearc basin sedimentation during the Late Jurassic in what have been interpreted as marginal marine to basin floor depositional settings (Wartes and others, 2011, 2013; LePain and others, 2013).

\section{Chisik Conglomerate Member (Oxfordian)}

The Chisik Conglomerate Member has a geographically limited distribution on the Iniskin Peninsula, extending for approximately $5 \mathrm{~km}$ from Iniskin Bay's east shore eastward to the Mount Pomeroy area (fig. 8; also Moffit, 1927; Kirschner and Minard, 1949; and Hartsock, 1954). The Iniskin Bay exposure of the Chisik is excellent and is the only traversable occurrence of this unit on the Iniskin Peninsula.

The base of the Chisik at Iniskin Bay is readily mappable at the onset of conglomerate beds overlying the Paveloff (fig. 9A). The base of the Naknek is similarly well expressed in the Mount Pomeroy area farther east, but occurs on an inaccessibly steep slope (fig. 8, yellow arrow); aerial reconnaissance of this conspicuous stratigraphic surface indicates the light-gray-weathering basal Naknek beds are probably conglomeratic and thus Chisik. However, these light-gray basal Naknek strata were not observed farther east, and no conglomerate occurs at the mappable but less distinct Paveloff-lower sandstone contact along the west shore of Oil Bay approximately $2 \mathrm{~km}$ east of the yellow arrow on figure 8 . These observations demonstrate that the Chisik depositionally pinches out laterally, transitioning entirely into lower sandstone member between these two localities (fig. 2). This geographically restricted expression of the Chisik is consistent with mapping by Moffit (1927), Kirschner and Minard (1949), and Hartsock (1954), but contrasts with mapping by Detterman and Hartsock (1966). 

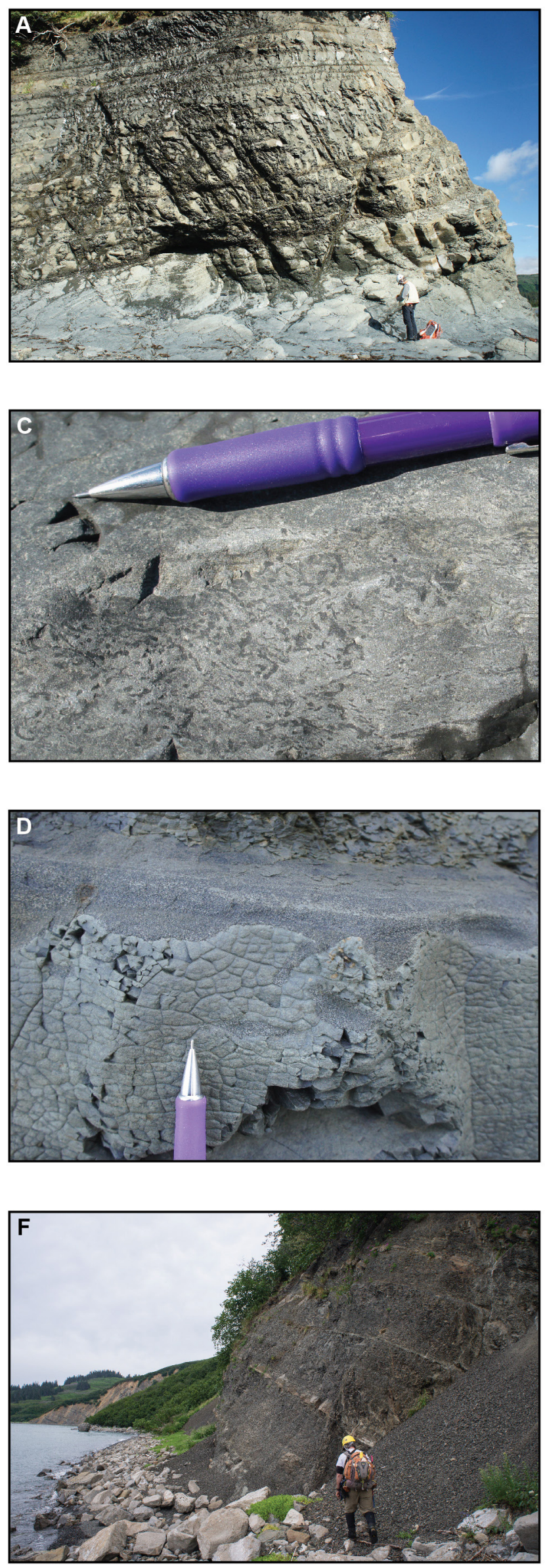
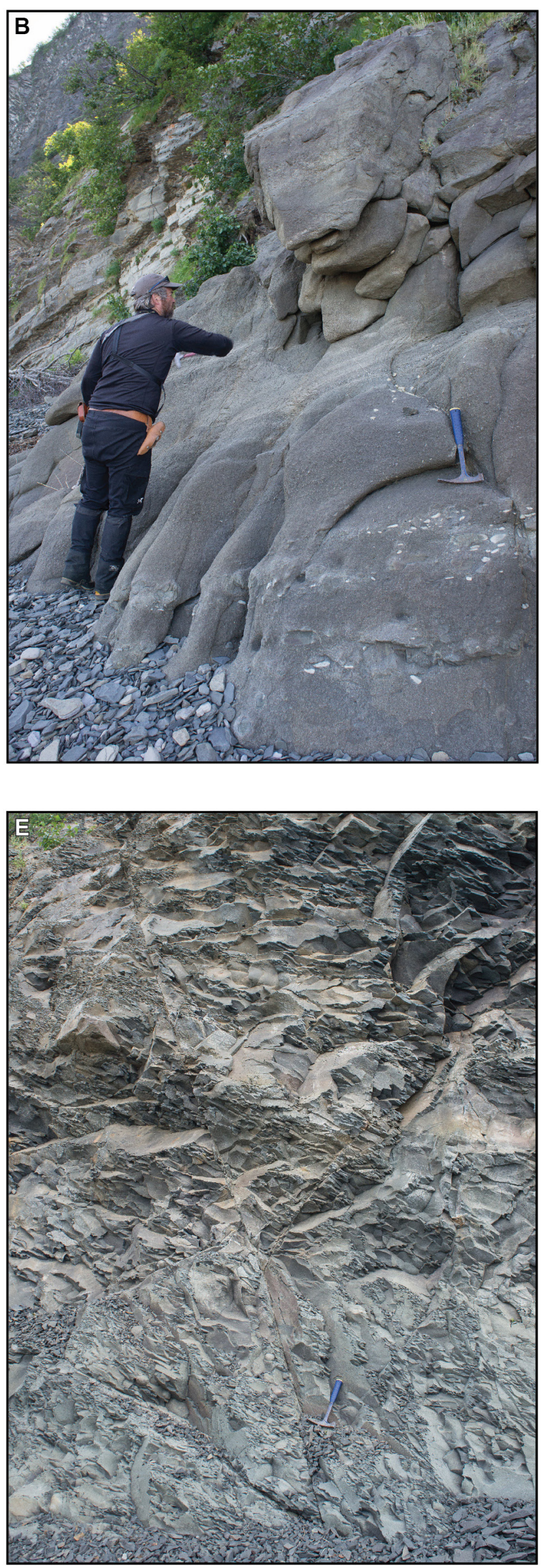
Figure 7 (left). Photographs exhibiting outcrop and lithologic characteristics of the Paveloff Siltstone Member, Chinitna Formation. (A) Excellent exposure of Paveloff, consisting of siltstone and sandstone along the west shore of Oil Bay. Geologist for scale. (B) Very-thick-bedded, amalgamated, granule- and pebble-bearing, medium- to coarse-grained sandstone in the sand-prone basal Paveloff along Chinitna Bay's south shore. Geologist and 31-cm-long hammer for scale. (C) Curvilinear Phycosiphon burrows filled with dark-gray siltstone and hosted within silty, very-fine sandstone. Pencil above rubberized grip is $1 \mathrm{~cm}$ diameter. (D) Sandy siltstone with intercalated, thin-bedded, sharp-based, finegrained sandstone, with probable Thalassinoides burrows immediately right of pencil tip. Centimeter-scale fracture pattern in sandy siltstone is common to the Paveloff, yielding small blocks that comprise talus aprons at the base of outcrops. Pencil at rubberized grip is $\sim 1.2 \mathrm{~cm}$ diameter. (E) Apparently very-thick-bedded, texturally structureless sandy siltstone. The primary sedimentary structures and textural variability of sedimentation units in these beds may have been destroyed post-depositionally by thorough bioturbation. Bedding in photograph dips gently from left to right. Hammer is $31 \mathrm{~cm}$ long. (F) Tan- to medium-brown-weathering, dominantly tabular-with subordinate ellipsoidalshaped-concretionary beds. Note also the small, centimeter-scale blocks that characteristically comprise Paveloff talus. Geologist for scale. Photographs by T.M. Herriott.

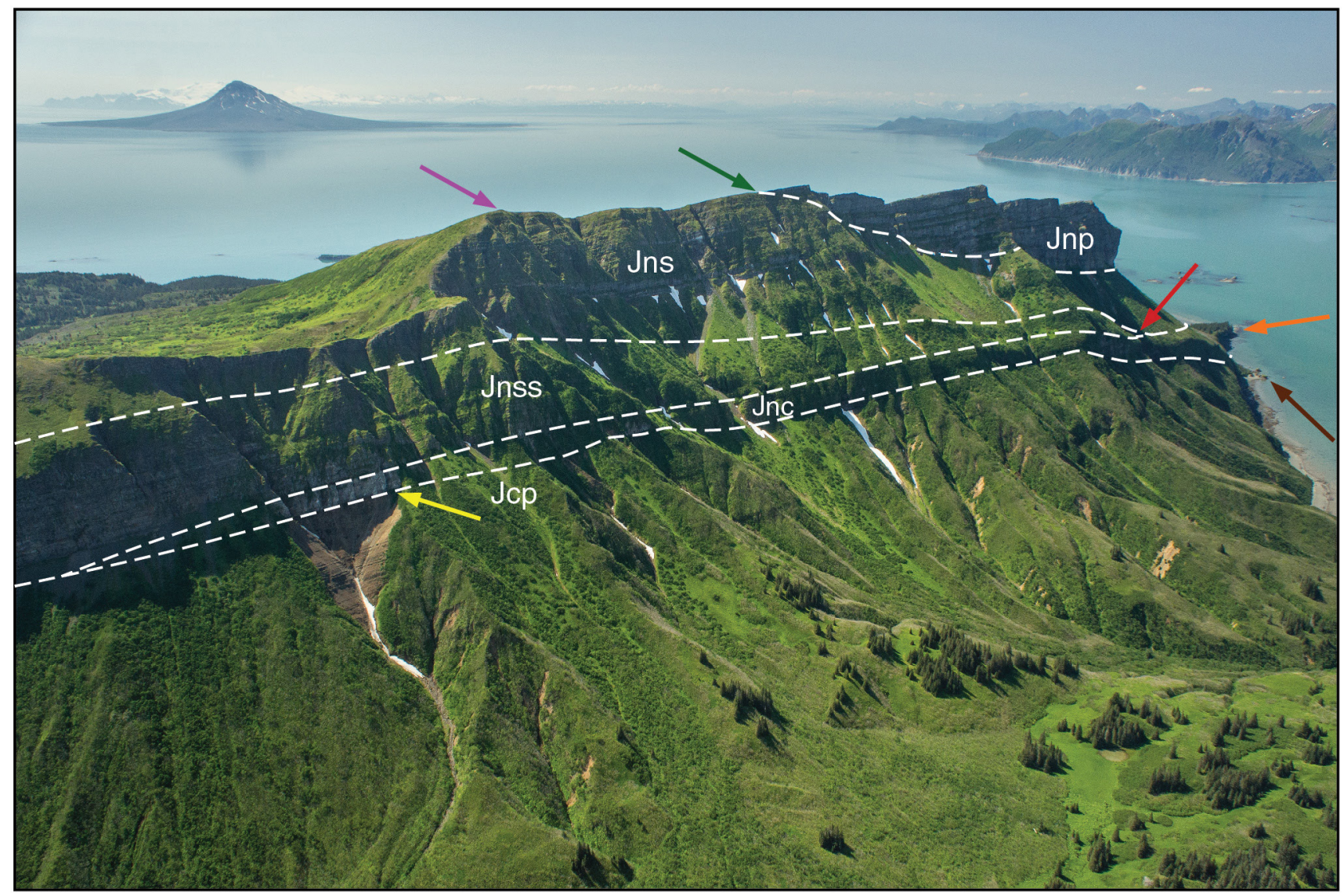

Figure 8. Oblique aerial view southwestward of the Mount Pomeroy area, portraying mappable characteristics of the Naknek Formation members and associated map unit contacts. Excellent exposures of Chisik (Jnc) crop out along Iniskin Bay (orange arrow). The Paveloff (Jcp)-Chisik contact at Iniskin Bay lies immediately southwest of The Toadstools (brown arrow). Farther east (toward left), the trace of the Chinitna-Naknek contact is on an inaccessibly steep slope, but is marked by an abrupt stratigraphic surface (yellow arrow). East of Iniskin Bay, the Chisik-Snug Harbor (Jns) contact grades laterally into a Chisik-lower sandstone member (Jnss) contact (red arrow; see text). Note also that Snug Harbor is recessive to the west, but comprises the summit of Mount Pomeroy (purple arrow) to the east. See the text for discussions of the Snug Harbor-Pomeroy (Jnp) relation (green arrow) in the Mount Pomeroy area. For sense of scale, Jnp cliffs above red arrow are $150 \mathrm{~m}$ tall. Augustine Volcano is visible at upper left of photograph. Photograph by T.M. Herriott. 

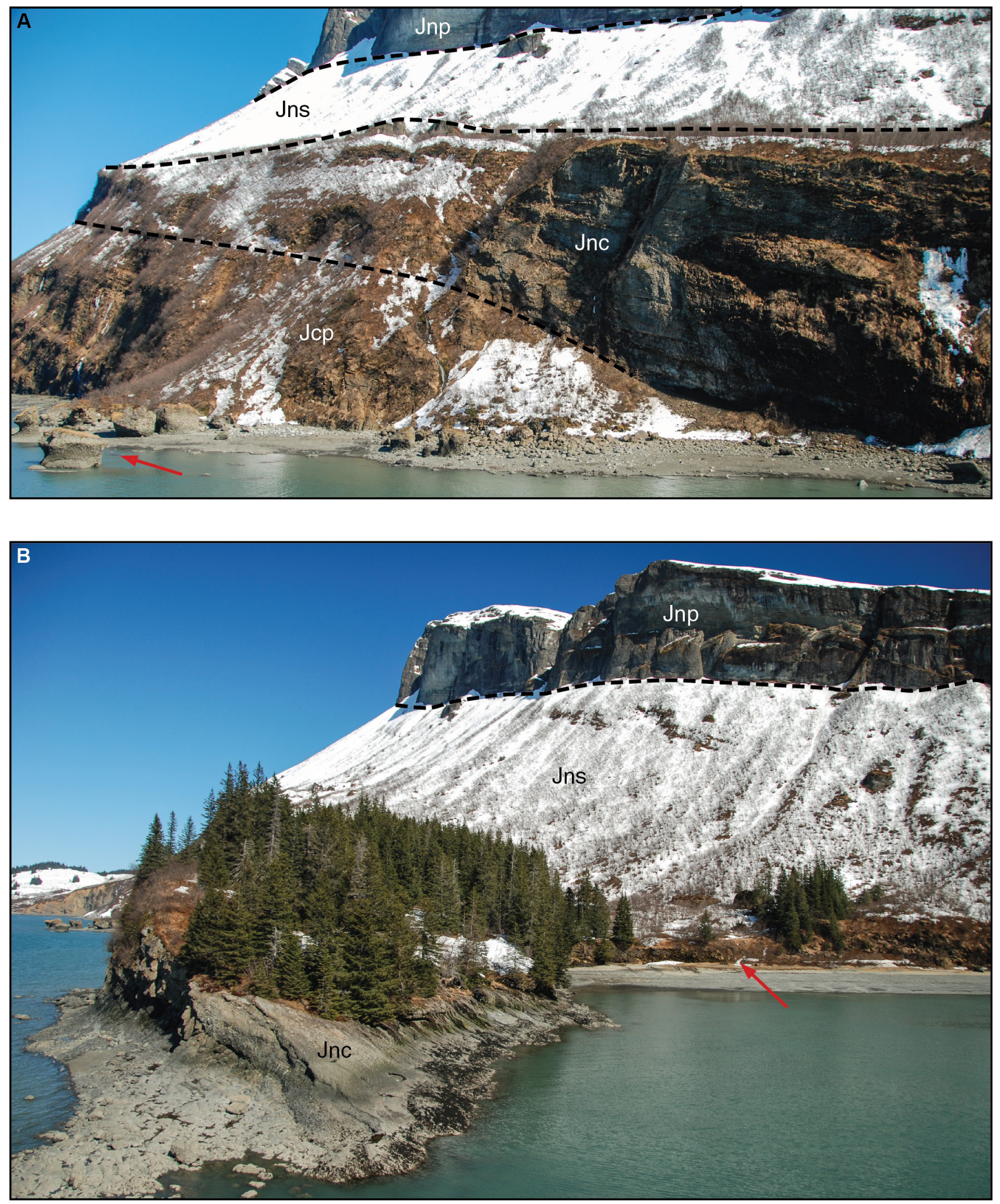

Figure 9. Oblique aerial photographs portraying mappable characteristics of the Chisik Conglomerate Member (Jnc) and associated map unit contacts along the east shore of Iniskin Bay. (A) View eastward of The Toadstools (red arrow) area, with the Chisik overlying Paveloff (Jcp). The Chisik is 100 m thick at Iniskin Bay (at right of photograph), for sense of scale. (B) View eastward of the top of Chisik (red arrow), which in this area is directly overlain by a recessive-weathering succession of Snug Harbor (Jns). Pomeroy Arkose Member (Jnp) strata crop out along the skyline in cliffs up to 150 $\mathrm{m}$ tall. Photographs by T.M. Herriott. 
The Chisik's top is poorly exposed along Iniskin Bay, but is mapped where boulder-bearing strata are abruptly overlain by a recessive, predominantly covered interval of Snug Harbor Siltstone Member (fig. 9B). East of Iniskin Bay, the upper Chisik contact stratigraphically transitions laterally from Chisik-Snug Harbor in the west to Chisik-lower sandstone in the east. We interpret this eastward transition to occur where a resistant topographic shoulder develops between Chisik and Snug Harbor (fig. 8, red arrow); this shoulder can be correlated with moderate confidence to the lower sandstone member-Snug Harbor contact in the area northeast of Mount Pomeroy. Our observations and the map pattern (fig. 2) reflect a marked eastward thinning of the Chisik and an even more marked eastward thickening of the lower sandstone member, yielding a greater than doubling of stratigraphic thickness of the basal Naknek (that is, sub-Snug Harbor Siltstone Member) interval between Iniskin and Oil bays.

The Chisik comprises poorly organized, thick- to very-thick-bedded, broadly lenticular-bodied, pebble to cobble to boulder conglomerate, with subordinate sandstone interbeds (fig. 10). The dominant igneous clast compositions suggest the gravel was sourced from the magmatic arc, with minor sedimentary clasts likely being rip-ups derived from the underlying Chinitna Formation (fig. 10A). Wartes and others (2013) summarized recent lithostratigraphic work on the Chisik, interpreting the unit as recording fan delta sedimentation; those authors reported an approximate $100 \mathrm{~m}$ thickness for the Chisik at Iniskin Bay (fig. 2).

\section{Lower Sandstone Member (informal) (Oxfordian)}

The lower sandstone member crops out extensively in the Tilted Hills, extending from the Mount Pomeroy area northeastward to the south shore of Chinitna Bay. In this outcrop belt, the lower sandstone member is typically exposed
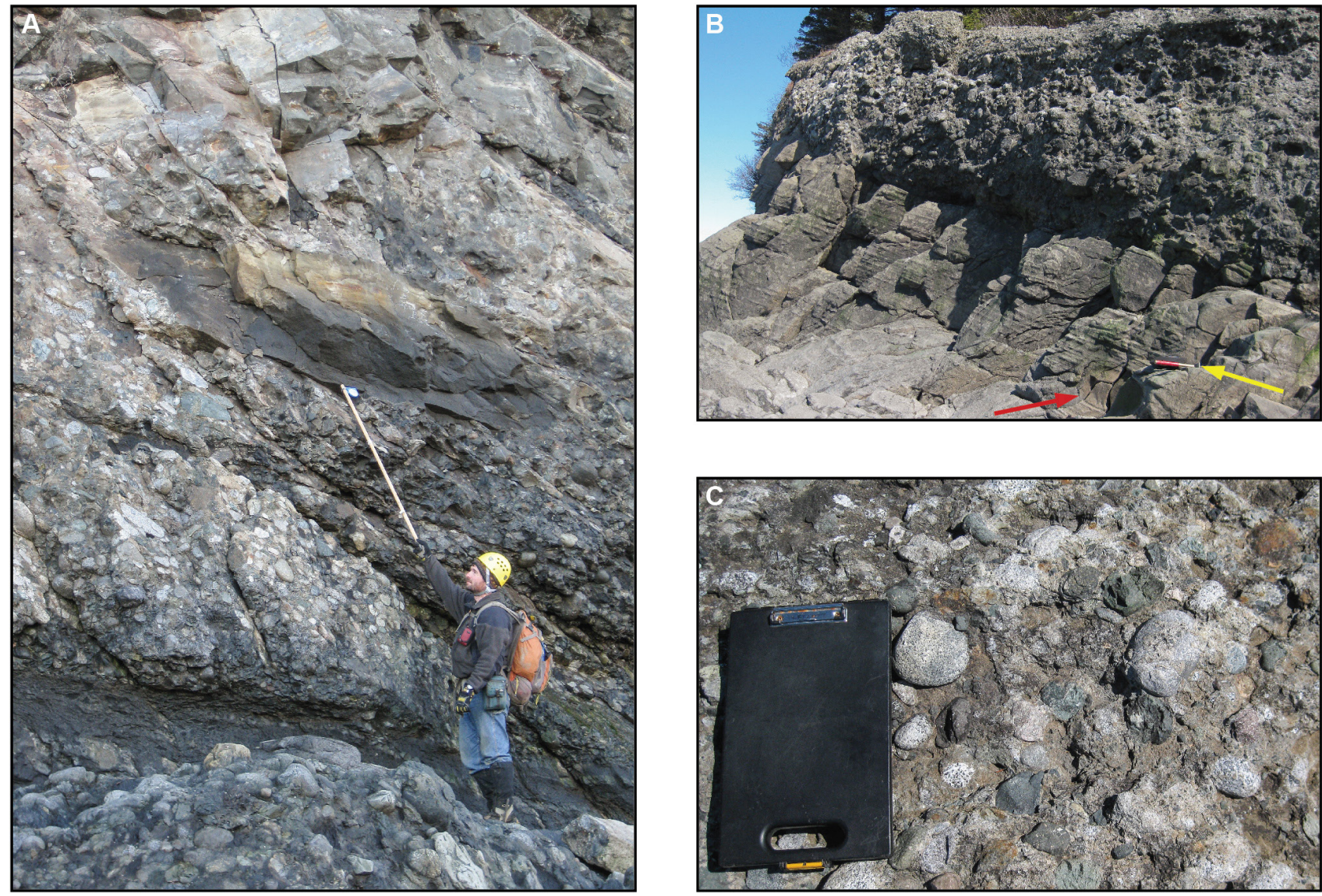

Figure 10. Photographs exhibiting outcrop and lithologic characteristics of the Chisik Conglomerate Member, Naknek Formation. (A) Exposure of very-thick-bedded, poorly organized, cobble and boulder conglomerate, with intercalated gravelly sandstone. The outsized sedimentary clast ( $4 \mathrm{~m}$ apparent long-axis dimension) immediately above Jacob staff was likely derived from the underlying Chinitna Formation. Geologist for scale. (B) A well-bedded sandstone package overlain by poorly organized cobble conglomerate. Note ovoid-shaped concretion (red arrow) below hammer handle. Hammer (yellow arrow) is $38 \mathrm{~cm}$ long. (C) Detailed view of poorly organized cobble conglomerate consisting of rounded igneous clasts sourced chiefly from the magmatic arc, with minor sedimentary clasts likely derived from the underlying Chinitna Formation. Clipboard is $25 \times 40 \mathrm{~cm}$ for scale. Photographs by T.M. Herriott. 
in ridges, peaks, and cliff faces (fig. 6) above what are commonly steep slopes consisting of Paveloff (fig. 4). The lower sandstone member is not present at Iniskin Bay, where the laterally equivalent Chisik lies between the Paveloff and Snug Harbor. Excellent, stratigraphically complete exposures of the lower sandstone member are on the west shore of Oil Bay and south shore of Chinitna Bay. An intermittently covered and fault-truncated section of the lower sandstone member is also accessible on Oil Bay's east shore.

The base of the lower sandstone member is typically moderately well exposed and mapped at the change from chiefly greener colored and less erosionally resistant strata of the Paveloff Siltstone Member to brown- and gray-weathering, coarser-grained, arkosic sandstones. Within inaccessible mountain-scale exposures, however, it is commonly challenging to consistently and accurately pick a Paveloff-lower sandstone contact, as the base of the lower sandstone does not usually exhibit its characteristic striped color scheme (medium-brown- and light-gray-weathering: fig. 11 A; also figs. 4 and 6). In these areas, only through weathering profile characteristics and/or examination of strata in nearby outcrops can the contact be confidently identified (fig. 11B; criteria outlined in Paveloff section above). The lower sandstone member locally overlies the Chisik Conglomerate Member in the Mount Pomeroy area.

The lower sandstone member's contact with the overlying Snug Harbor Siltstone Member is distinct, occurring at the abrupt transition from chiefly thicker-bedded sandstone to dominantly thinner-bedded siltstone (fig. 11C). The Snug Harbor also exhibits conspicuous, outcrop-parallel fracture faces that are covered by whitish-gray-weathering, fracture-filling mineralization (fig. 11C). The juxtaposition of lower sandstone-Snug Harbor lithofacies and bedding character commonly yields small dip slopes or recessive-weathering zones along the uppermost bed(s) of the lower sandstone (fig. 11D). This field relation is consistent with work by Wartes and others (2013), who hypothesized that the shelfal lower sandstone member is overlain by outer shelf to slope deposits of Snug Harbor. The sharp lower sandstone-Snug Harbor contact thus potentially marks an abrupt landward shift of paleoshoreline, with the proposed flooding surface lying in the recessive-weathering zone immediately above the lower sandstone (fig. 11D).

The lower sandstone member dominantly consists of tan- to medium-brown- to gray-brown- to light-gray-weathering, tabular, thin- to thick-bedded, arkosic, very fine- to fine-grained sandstone (fig. 12A), with subordinate thin-bedded siltstone and gray-weathering, medium- to very-thick-bedded, medium- to very-coarse-grained sandstone (fig. 12B). Convolute lamination (fig. 12C) and bioturbation, including Thalassinoides, Rhizocorallium, Diplocriterion, Planolites, and Phycosiphon (fig. 12D) trace fossils, as well as thoroughly burrow-churned textures (fig. 12E), are common in this unit. Also, despite the nearby Chisik-lower sandstone lateral transition in the Mount Pomeroy area discussed above, gravel-sized clasts in the lower sandstone are exceedingly rare (fig. 12F). Wartes and others (2013) summarized recent lithostratigraphic work on the lower sandstone member in Oil Bay. A detailed section through the unit measured with a Jacob staff along the west shore of Oil Bay is $234 \mathrm{~m}$ thick, and a map-scale thickness calculation on the south shore of Chinitna Bay yielded an estimated stratigraphic thickness of $253 \mathrm{~m}$ (fig. 2).

\section{Snug Harbor Siltstone Member (Oxfordian to Kimmeridgian[?])}

The Snug Harbor Siltstone Member is present throughout the Tilted Hills in recessive slopes and swales, as well as resistant peaks and ridges (figs. 4, 8, 9, and 11B and D). The Snug Harbor crops out between the erosionally resistant Chisik/ lower sandstone interval and the rampart-like cliffs of the Pomeroy Arkose Member (figs. 9B and 11B and D). Although Snug Harbor outcrops at Iniskin Bay are limited, excellent exposures of the unit were observed along the west shore of Oil Bay and south shore of Chinitna Bay. Notable sections of Snug Harbor were also observed in northwest-trending ridges near South Chinitna Mountain and Mount Chinitna (fig. 1).

The lower sandstone-Snug Harbor contact is reflected in most outcrops as an abrupt change in bedding character, weathering color and profile, and lithology (fig. 11C and D; also Lower Sandstone Member section above). Although the Snug Harbor is chiefly finer grained than the underlying lower sandstone member, notable sandstone and conglomerate beds were observed in the unit. The characteristic whitish-gray-weathering, fracture-filling mineralization (see fig. 11C), along with the generally recessive lower portion of the Snug Harbor (figs. 9 and 11D), further render the base of this unit one of the most readily mappable contacts in the Tilted Hills. The characteristically sharp and conspicuous lower sandstone-Snug Harbor contact may record an abrupt landward shift of paleoshoreline (Wartes and others, 2013).

The Snug Harbor-Pomeroy Arkose contact is generally the most prominent contact on the Iniskin Peninsula, commonly present at the base of $>100$-m-high cliff faces (figs. 8, 9B, and 11B and D). The darker-gray-weathering, thinner-bedded, finer-grained Snug Harbor contrasts sharply with the overlying lighter-gray-weathering, thicker-bedded, coarser-grained Pomeroy (fig. 13). The top of the Snug Harbor is typically sharp and mapped at the base of amalgamated arkosic sandstone packages that form the ubiquitous cliffs of the lower Pomeroy (fig. 13). However, we observed numerous localities where the upper Snug Harbor includes a transitional, Pomeroy-like arkosic lithofacies that presages onset of sedimentation of the tens-of-meters-thick amalgamated arkose packages of the Pomeroy (fig. 13). Nevertheless, the lithostratigraphically more significant — and consistently mappable — surface lies at the stratigraphically highest occurrence of Snug Harbor facies beds, which are overlain by the coarser-grained and thicker-bedded sedimentation units of the basal Pomeroy. 

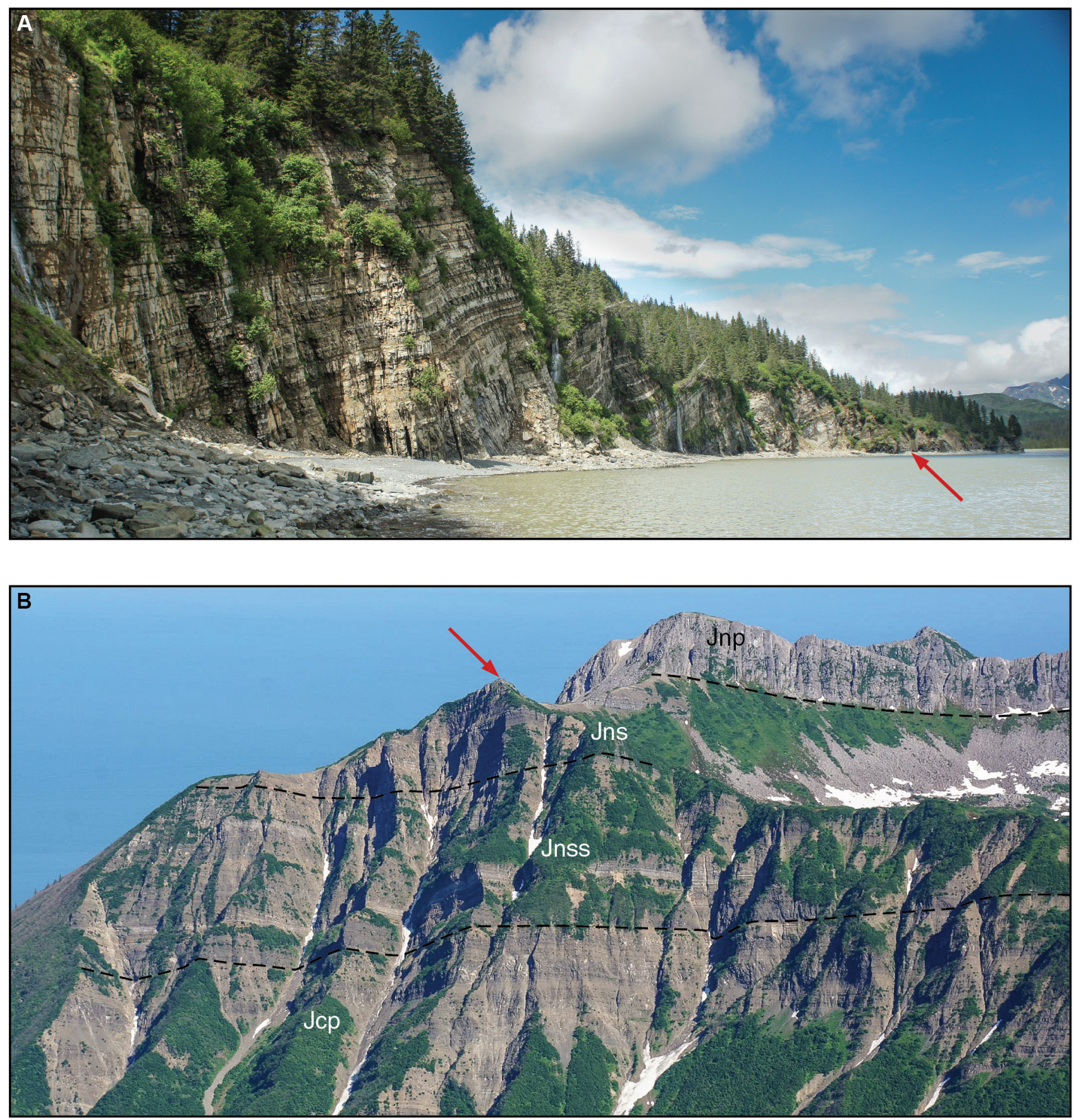

Figure 11. Photographs portraying mappable characteristics of the lower sandstone member and associated map unit contacts. (A) View northwestward along the west shore of Oil Bay, with sea-cliff exposures of the characteristic striped color scheme (medium-brown- and light-gray-weathering) of the lower sandstone member. The Paveloff-lower sandstone contact (red arrow) at this locality is mapped near the base of the striped lower sandstone facies, but elsewhere the contact lies several tens of meters below the striped facies (see text for mapping criteria). Photograph by T.M. Herriott. (B) Oblique aerial view eastward of massif $1.25 \mathrm{~km}$ southwest of Sea Otter Point (fig. 1). The lower sandstone (Jnss) here is not color-striped at its base, but careful examination of lithofacies, color, and sediment composition along the south shore of Chinitna Bay permits identification of a mappable Paveloff (Jnp)-lower sandstone contact across this mountain face. Note also the swale and hill/peak weathering profile of the Snug Harbor Siltstone Member (Jns) along the photograph's left skyline. Boulder and cobble conglomerate beds of the Snug Harbor crop out at the peak demarcated by the red arrow. Cliffs of the Pomeroy Arkose Member (Jnp) comprise the skyline at right of photograph. The lower sandstone at nearby Chinitna Bay is $\sim 250 \mathrm{~m}$ thick, for sense scale. Photograph by M.A. Wartes. 

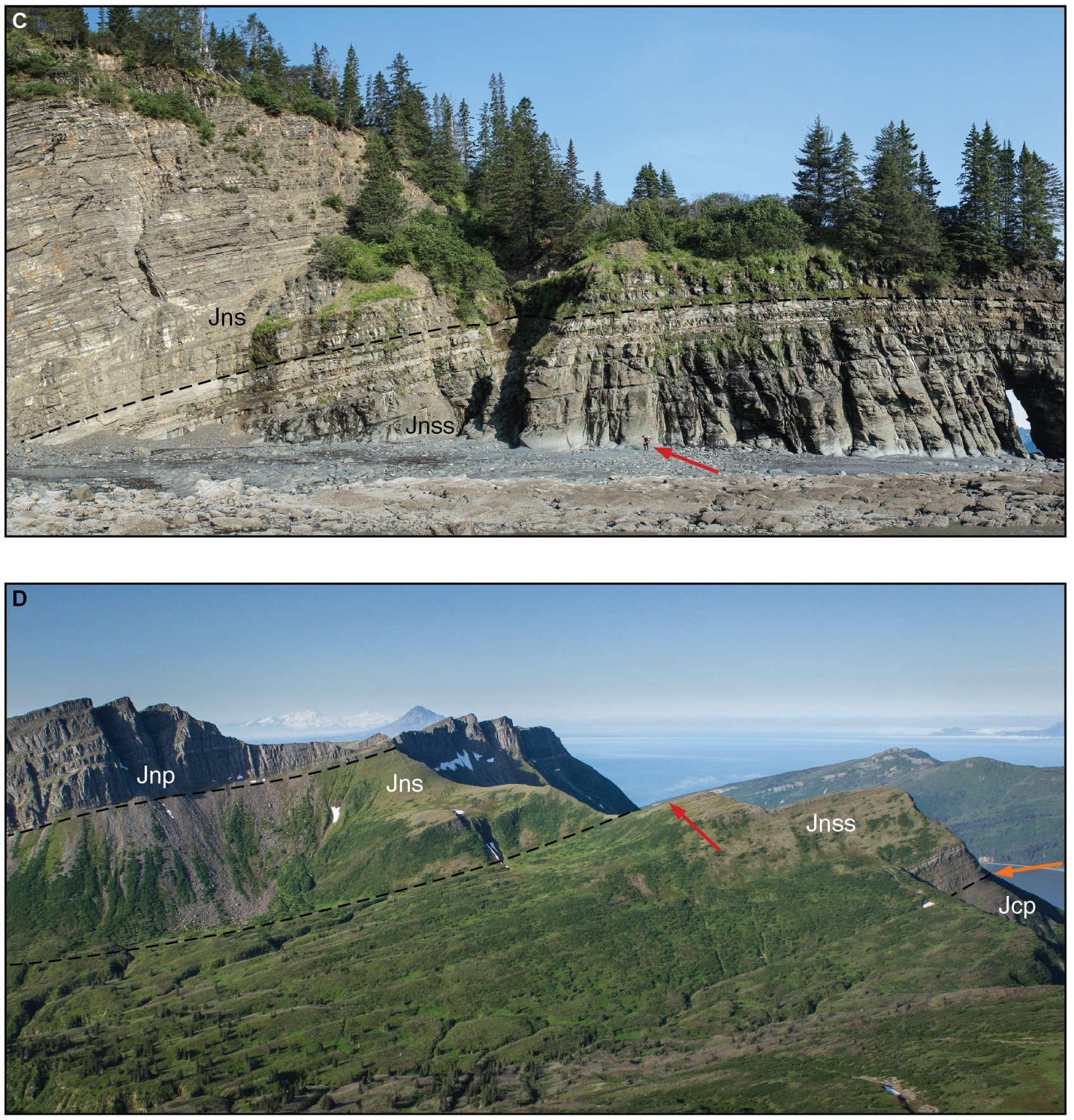

Figure 11 (continued). (C). View northwestward in a small cove along the west shore of Oil Bay. Finer-grained and thinnerbedded strata of the Snug Harbor Siltstone Member (Jns) overlie coarser-grained and thicker-bedded strata of the lower sandstone member (Jnss). The whitish-gray-weathering, fracture-filling mineralization on portions of the outcrop face at left of photograph is characteristic of Snug Harbor. Geologist for scale (red arrow). Photograph by T.M. Herriott. (D) Oblique aerial view southwestward of Cy Peak (immediately right of red arrow) and Shark Tooth Hill (left skyline) area, with typical weathering profiles of Paveloff (Jcp) through Pomeroy Arkose (Jnp) members. A characteristic dip slope in the uppermost lower sandstone member (Jnss) bed(s) marks the abrupt contact with Snug Harbor (Jns); the typical, alternating swale and hill/peak weathering profile of the Snug Harbor is observed here. Note also the break in slope at the Paveloff-lower sandstone contact (orange arrow). Pomeroy cliffs comprise the photograph-center and photograph-left skyline. The Snug Harbor here is 285 m thick for sense of scale. Photograph by T.M. Herriott. 

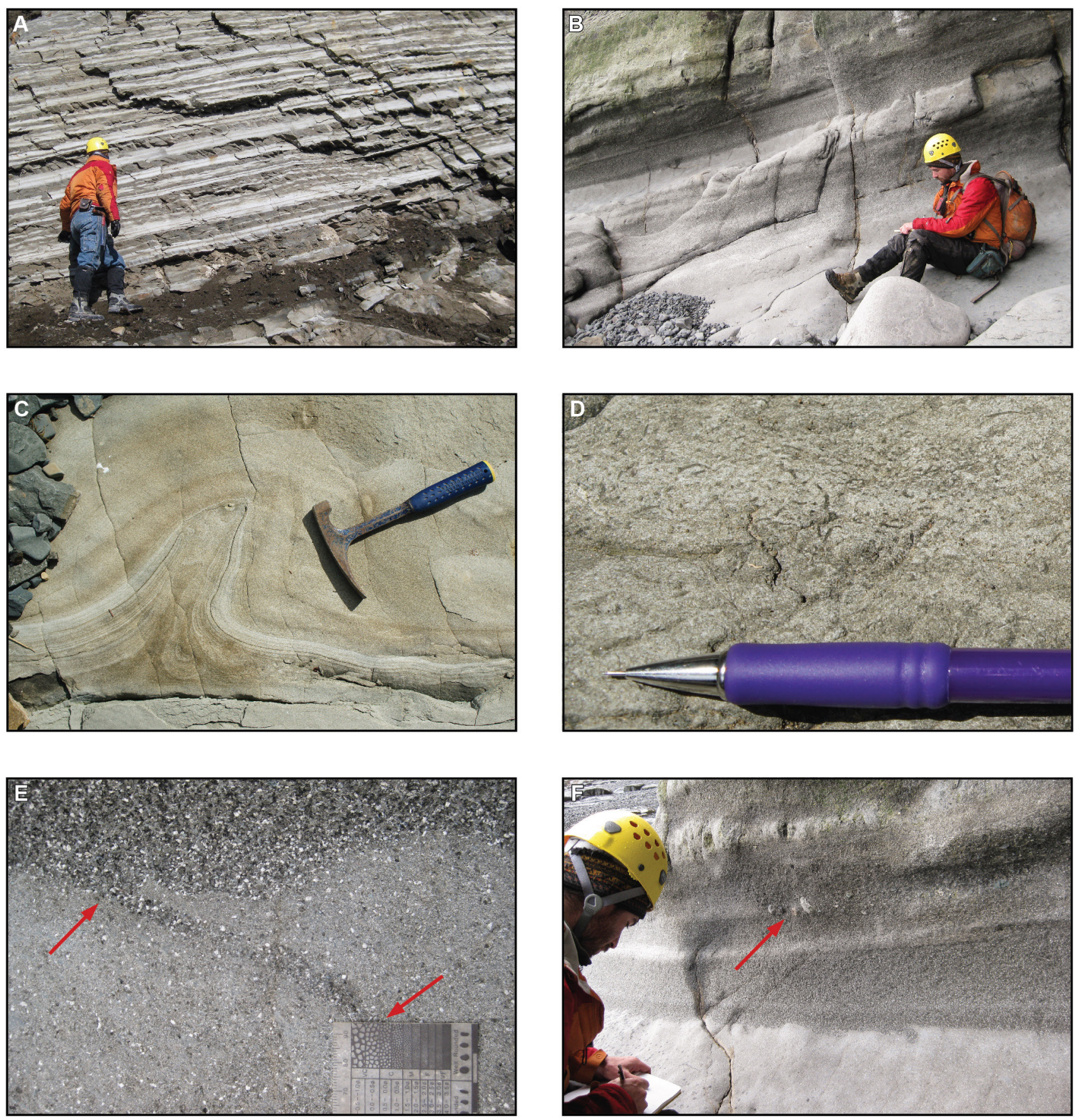

Figure 12. Photographs exhibiting outcrop and lithologic characteristics of the lower sandstone member, Naknek Formation. (A) Typical exposure of color-striped (gray- and brown-weathering), thin- to medium-bedded, tabular, arkosic, very-fine- to fine-grained sandstone beds along Oil Bay's west shore. Geologist for scale. (B) Outcrop of medium- to very-thick-bedded, medium- to coarse-grained sandstone beds that are structureless to faintly stratified and pervasively bioturbated. (C) Convolute laminations are commonly observed in fine-grained sandstone beds of the lower sandstone member. Hammer is $31 \mathrm{~cm}$ long. (D) Discrete trace fossils are present throughout much of the lower sandstone member; curvilinear, siltstone-filled tubes hosted in very-fine-grained sandstone immediately above pencil are probable Phycosiphon. Pencil above rubberized grip is $1 \mathrm{~cm}$ diameter. (E) A very-coarse-grained sandstone overlying mediumgrained sandstone. A burrow (between red arrows) records bioturbation, and "floating" very-coarse sand grains in the medium-grained sandstone yield a "bimodal" texture that is further suggestive of synsedimentary biogenic activity. Scale on left of grain-size card in mm. (F) Pebbles (red arrow) in the coarse sandstone facies of the lower sandstone member; gravel-sized clasts are rarely observed in the lower sandstone. Geologist for scale. Photographs by T.M. Herriott. 


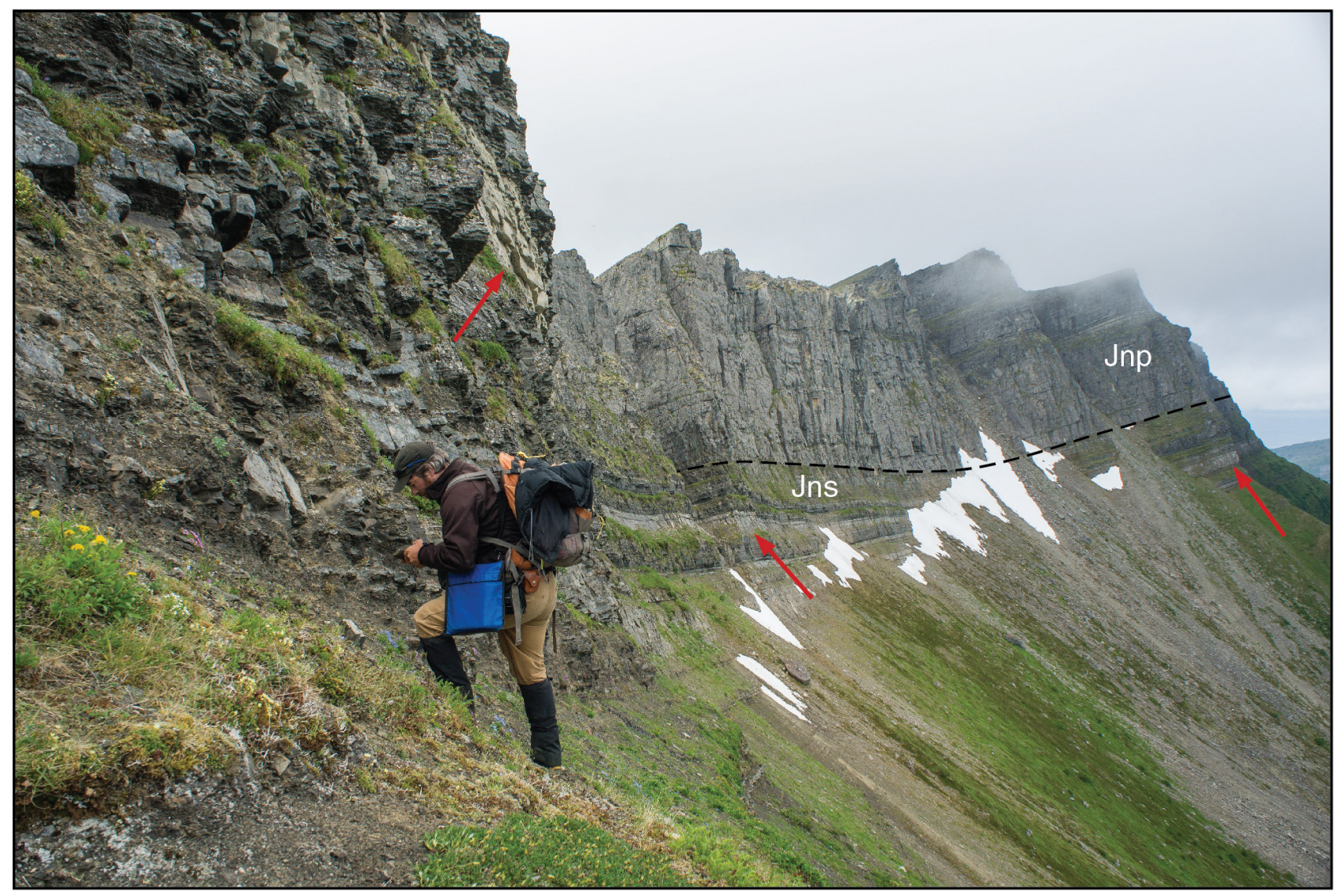

Figure 13. Photograph portraying mappable characteristics of the Snug Harbor (Jns)-Pomeroy (Jnp) contact. View southwestward along cliff face $\sim 1 \mathrm{~km}$ west of Shark Tooth Hill. Outcrop in foreground (at left of photograph) comprises the transitional facies that lies within the uppermost Snug Harbor; for example, very thick arkose beds in this interval (marked by red arrows) are essentially Pomeroy facies, but we have consistently mapped these beds with the Snug Harbor. The Snug Harbor-Pomeroy contact is mapped at the base of the cliff-forming, amalgamated arkosic sandstone beds. Geologist for scale. Photograph by T.M. Herriott.

We observed an anomalous relation between the Snug Harbor and Pomeroy in the area immediately west of Mount Pomeroy where a package of siltstone and very-fine-grained sandstone that is distinctly Snug Harbor lithofacies crops out on the north-facing flanks of the mountain (fig. 14). However, approximately $2 \mathrm{~km}$ along strike to the west, greater than 100 $\mathrm{m}$ of the Mount Pomeroy area Snug Harbor strata are absent and the interval is occupied by the basal cliff-forming beds of the Pomeroy Arkose Member (fig. 8). The resulting map pattern (fig. 2) is largely consistent with geologic mapping by Kirschner and Minard (1949) and Hartsock (1954), but contrasts with later mapping by Detterman and Hartsock (1966). Although the gradational transition upsection between the Snug Harbor and Pomeroy is nearly ubiquitous in the Tilted Hills, the lateral transition described here was not observed elsewhere. At least two hypotheses may account for this relation, including: (1) the cliff-face transition records a true lateral facies change or (2) Snug Harbor strata were post-depositionally eroded and that erosional relief was later filled by sediments of the Pomeroy Arkose Member. A faulted relation is not supported by our field observations. Further synthesis of our observations is pending and will yield a preferred hypothesis for this lithostratigraphically significant Snug Harbor-Pomeroy field relation.

The Snug Harbor dominantly comprises dark-gray- to dark-gray-brown-weathering, tabular, thin- to thick-bedded siltstone, sandy siltstone, and very-fine-grained sandstone (fig. 15A and B). Thin-bedded, sharp-based, normally graded sandstone beds are locally observed (fig. 15C), and conglomeratic sandstone (fig. 15D) and conglomerate (fig. 15E) are minor but notable constituents of the Snug Harbor. Strata in this unit are very well indurated and commonly fractured conchoidally, yielding outcrops that commonly disaggregate into small, angular fragments (fig. 15B). Evidence of bioturbation in the Snug Harbor is relatively sparse, although Phycosiphon and probable Thalassinoides (fig. 15F) were observed. White-weathering, non-calcareous mineralization is common to fracture faces, contrasting well with the dark color of this unit (figs. $11 \mathrm{C}$ and 15A and B). Calcareous, orange-weathering concretionary horizons are locally well developed (fig. 15G). The Snug Harbor Siltstone Member also exhibits the most laterally consistent weathering profile (fig. 16) of any of the map units in the Tilted Hills, further aiding in the unit's mappability. Meter-scale, coarsening- and thickening(?)-upward parasequences are common in the lower Snug Harbor (figs. 15H and 16). An arkose-prone interval typically crops out in the upper third of the unit 


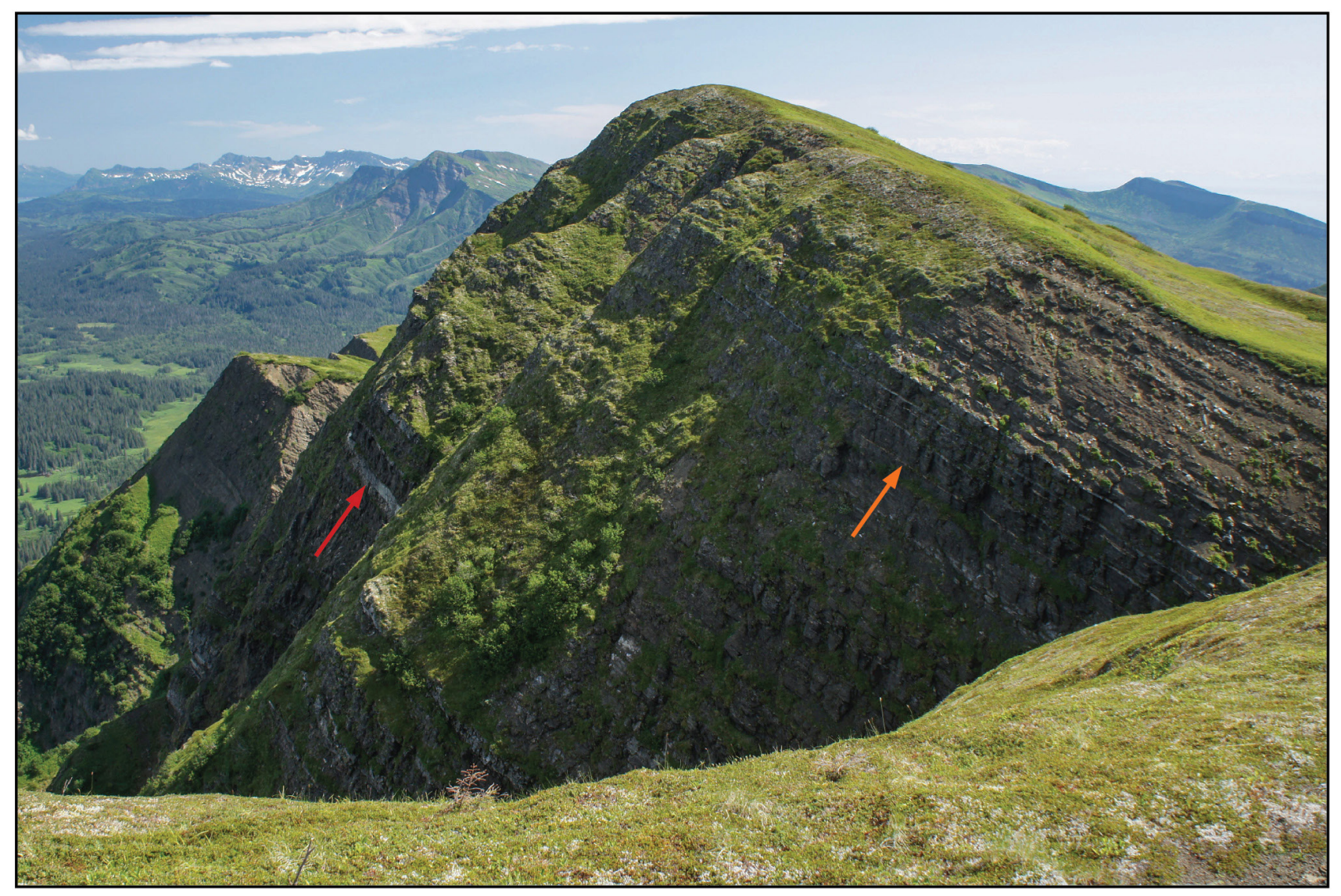

Figure 14. View eastward of Mount Pomeroy, with exposure of Snug Harbor Siltstone Member on the peak's northern flanks. Some very thick (red arrow) and thin (orange arrow) beds of Pomeroy Arkose Member facies are present in this uppermost section of Snug Harbor, but the overall thinner-bedded and finer-grained characteristics of these strata are distinctly mappable as Snug Harbor. However, approximately $2 \mathrm{~km}$ to the west, these outcrops transition laterally into a greater than 100-m-thick package of cliff-forming strata that are unequivocally mappable as Pomeroy (see text for discussion; fig. 8).

(fig. 13) and is interpreted as a precursor to deposition of the Pomeroy Arkose Member. Map-scale thickness calculations yielded estimated stratigraphic thicknesses of $252 \mathrm{~m}$ (Iniskin Bay), $259 \mathrm{~m}$ (Oil Bay), $285 \mathrm{~m}$ (Shark Tooth Hill) (fig. 1), and 235 m (South Chinitna Mountain) (fig. 2).

\section{Pomeroy Arkose Member (Kimmeridgian)}

The Pomeroy Arkose Member crops out extensively in the Tilted Hills, forming most of the area's highest peaks and cuestas and largest flatirons (figs. 3, 9B, 11B and D, 13, and 15H). Erosionally resistant, amalgamated arkose and arkosic conglomerate packages in the Pomeroy are typically tens to hundreds of meters thick, forming cliffs and precipitously steep slopes that are difficult to access. However, Pomeroy strata are traversable in sea cliff exposures along Iniskin, Oil, Dry, and Chinitna bays, as well as the Cook Inlet coast. The Pomeroy conspicuously crops out above the swales, hills, and peaks of the Snug Harbor Siltstone Member; the unit's top is not exposed in the Tilted Hills.

Changes in bedding character, weathering color and profile, and lithology across the Snug Harbor-Pomeroy contact are typically quite evident (figs. 9, 11B and D, and 13; also Snug Harbor Siltstone section above). The contact is everywhere mapped at the base of a thick succession of amalgamated, light-gray-weathering arkosic sandstone, which commonly forms cliff faces greater than $100 \mathrm{~m}$ tall. Numerous arkose beds were observed in the upper Snug Harbor that may be interpreted as Pomeroy facies deposits; however, as noted above, we include these beds with the Snug Harbor because we view the onset of exclusively amalgamated arkosic sedimentation as marking the more consistently mappable and lithostratigraphically significant surface between the two members. Wartes and others (2013) hypothesized that the Snug Harbor-Pomeroy contact may reflect a shift in depositional environment from slope to lower slope or basin floor sedimentation and our mapping-based observations remain consistent with this view.

Previous studies of the Pomeroy have documented significant lithologic variability in this arkosic unit (Kirschner and Minard, 1949; Hartsock, 1954; Detterman and Hartsock, 1966; Wartes and others, 2013). Some generalized lithofacies include: (1) gray-weathering, dominantly tabular, thin- to very-thick-bedded, commonly amalgamated, arkosic sandstone 

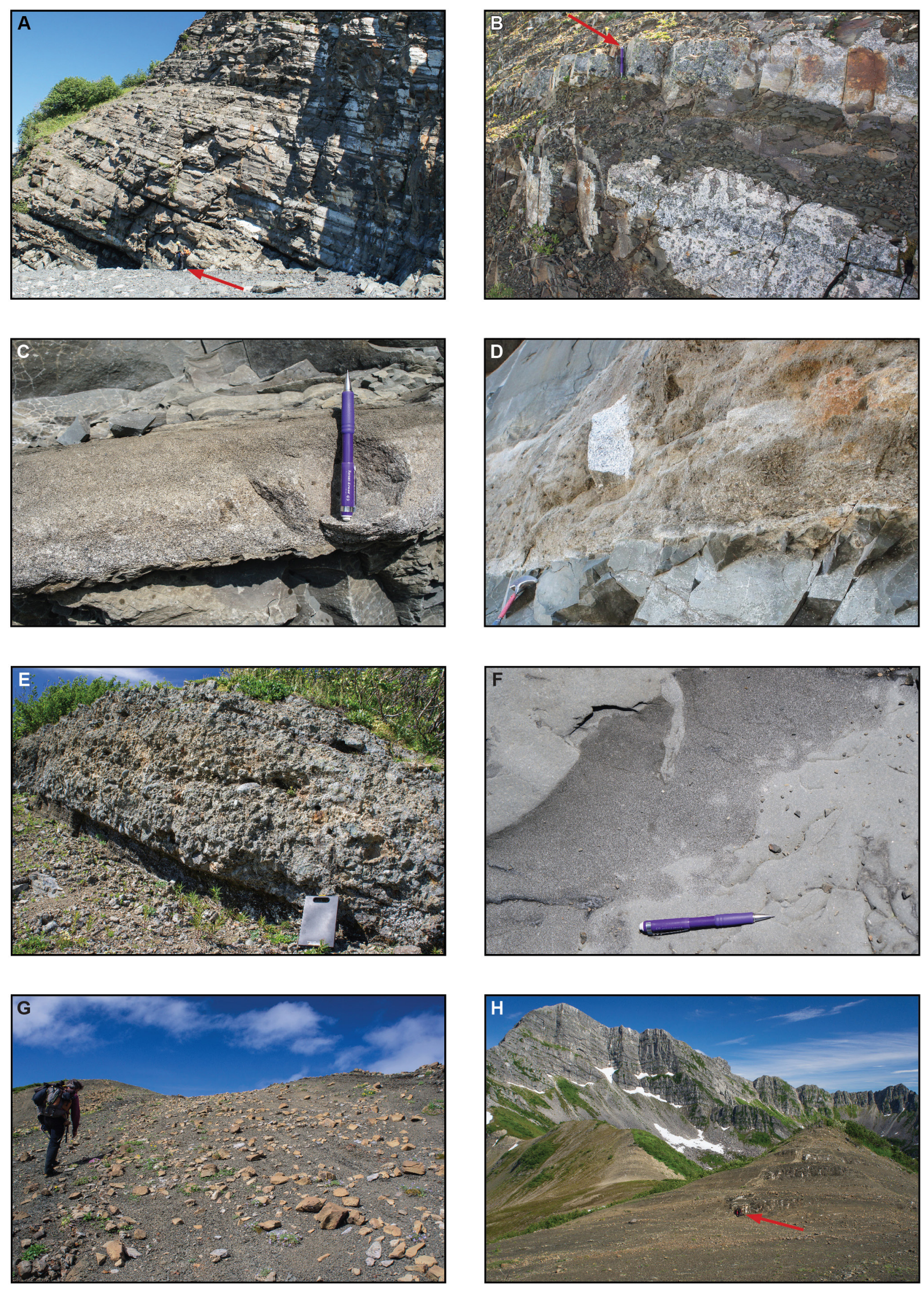
Figure 15 (left). Photographs exhibiting outcrop and lithologic characteristics of the Snug Harbor Siltstone Member, Naknek Formation. (A) Exposure of Snug Harbor along the east shore of Oil Bay, exhibiting dark-gray- to dark-gray-brownweathering, thin- to thick-bedded siltstone, sandy siltstone, and subordinate sandstone. Note mineralized fracture faces in shadow at right of photograph. Geologist for scale (red arrow). (B) Siltstone and very-fine-grained sandstone facies, with excellent expression of mineralized fracture faces. As is common in the Snug Harbor, this outcrop disaggregates into small, angular blocks along centimeter-scale, commonly conchoidal fractures. Pencil (red arrow) is $14 \mathrm{~cm} \mathrm{long.} \mathrm{(C)}$ Thin-bedded, sharp-based, normally graded sandstone bed of the chiefly finer-grained siltstone and sandy siltstone of the Snug Harbor. Pencil is $14 \mathrm{~cm}$ long. (D) Thick-bedded, boulder-bearing, conglomeratic sandstone facies is a minor but commonly observed lithofacies of Snug Harbor. Hammer head is $16 \mathrm{~cm}$ long. (E) Very-thick-bedded, boulder and cobble conglomerate in the Snug Harbor is only locally observed, but this facies is rather striking in the context of this chiefly finer-grained unit. This conglomerate bed crops out on an unnamed peak $1.25 \mathrm{~km}$ southwest of Sea Otter Point (red arrow, fig. 11B). Clipboard is $25 \times 40 \mathrm{~cm}$ for scale. (F) Shaft-like trace fossils (Thalassinoides[?]) hosted in sandstone are immediately above pencil and at center-top of photograph. Pencil is $14 \mathrm{~cm}$ long. (G) Tan-orange-weathering calcareous concretionary horizons are locally well developed in the Snug Harbor, forming blocky rubble in intervals of dominantly chippy-weathering siltstone. Geologist for scale. $(\mathrm{H})$ View eastward of Mount Chinitna, with meter-scale, coarsening- and thickening(?)-upward parasequences in foreground at right of photograph. Note the typical swales and hills in the brown-weathering Snug Harbor, and the steep cliff faces of basal Pomeroy along the skyline. Field backpack in foreground for scale (red arrow). Photographs by T.M. Herriott.

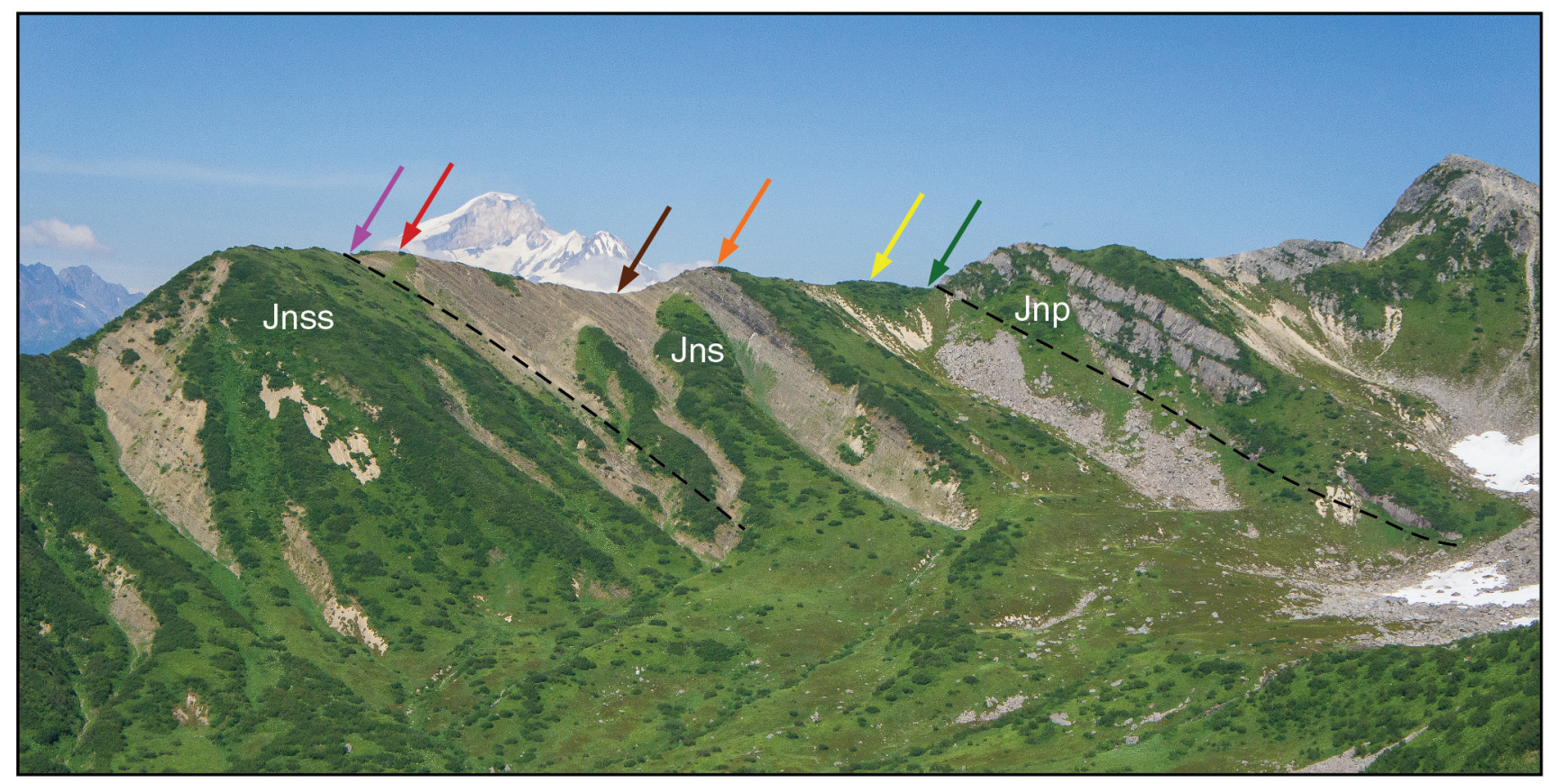

Figure 16. View northeastward of a ridge west of Griffin Creek with characteristic weathering profile of the Snug Harbor Siltstone Member (Jns) in the Tilted Hills area. Beds immediately overlying the sharp contact with the lower sandstone (Jnss) are recessive (pink arrow), but are in turn overlain by a moderately resistant hill-forming package (red arrow); a lower-middle recessive interval (brown arrow) lies between this lower hill and a prominent mid-Snug Harbor resistant package (orange arrow). Numerous intercalated Pomeroy-like facies beds occur in the upper part of the Snug Harbor, yielding a moderately resistant interval (yellow arrow). A thin, uppermost Snug Harbor recessive interval is locally well developed (green arrow), but elsewhere is lacking; in the latter case, the Pomeroy facies-bearing zone of the Snug Harbor (yellow arrow) abruptly transitions into the basal, amalgamated sandstone of the Pomeroy Arkose Member (Jnp) (see text for discussion). For sense of scale, the Snug Harbor is commonly 250 m thick in the area. Snow- and ice-covered summit of Iliamna Volcano is visible in background at left of photograph. Photograph by T.M. Herriott. 

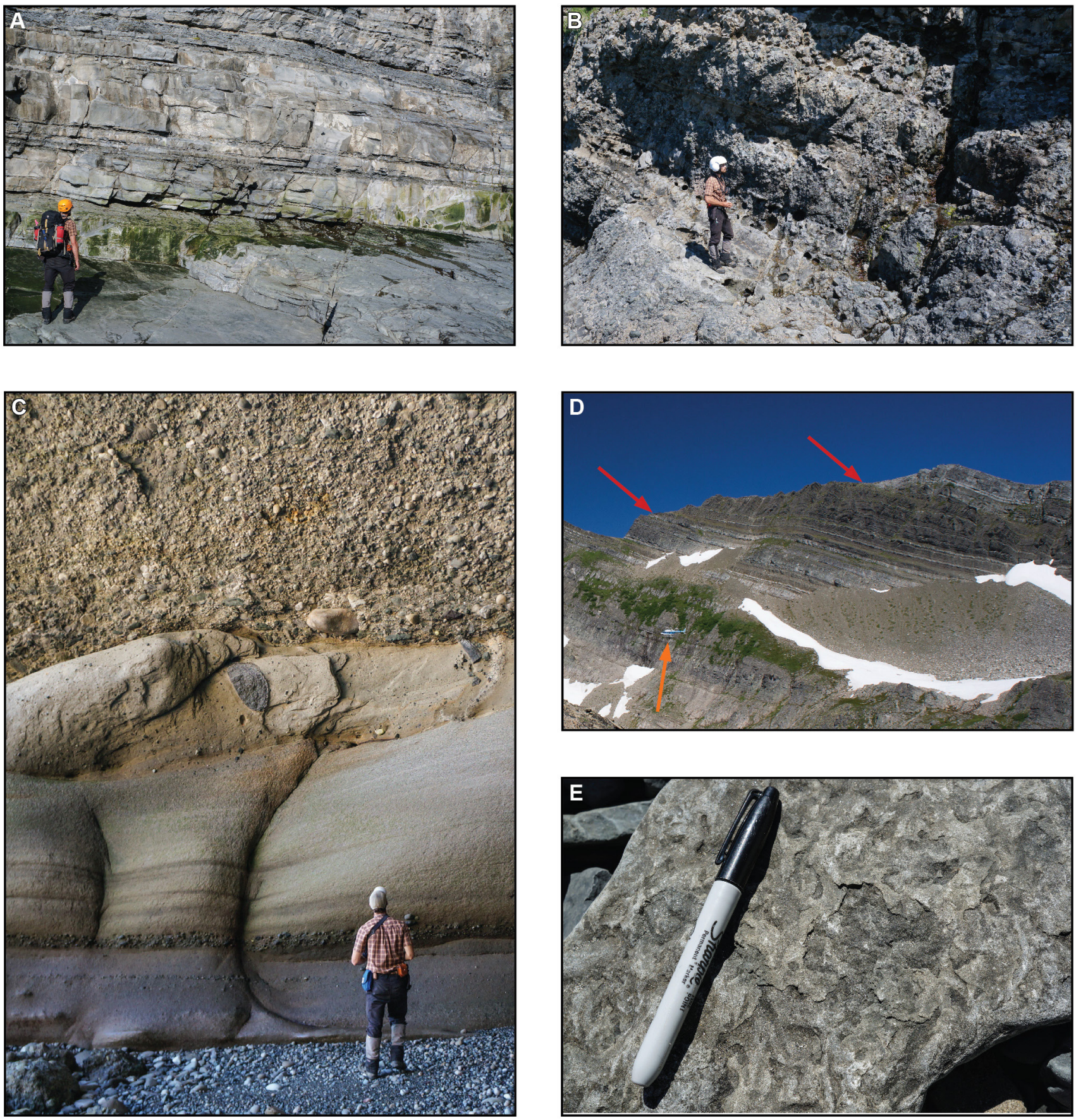

Figure 17. Photographs exhibiting outcrop and lithologic characteristics of the Pomeroy Arkose Member, Naknek Formation.

(A) Seacliff exposure near Chinitna Point of tabular to channelized beds of arkosic sandstone and siltstone. Geologist for scale. Photograph by M.A. Wartes. (B) Scott Island exposure of tabular to channelized conglomerate and associated arkosic sandstone of the lowermost Pomeroy. Photograph by M.A. Wartes. (C) Channelized and cross-stratified arkosic sandstone and pebble, cobble, and boulder conglomerate of the locally uppermost Pomeroy. This lithofacies is exposed extensively along the Cook Inlet coast southeast of South Chinitna Mountain. Geologist for scale. Photograph by M.A. Wartes. (D) View northeastward near South Chinitna Mountain of a conspicuously darker-weathering, comparatively recessive, thinner-bedded and finer-grained Pomeroy interval (strata between red arrows). Note helicopter at lower left of photograph for sense of scale. Photograph by T.M. Herriott. (E) Textural and color mottling in this sandstone indicate bioturbation in Pomeroy strata that crop out along the Cook Inlet coast east of Mount Chinitna. Marker is 14 $\mathrm{cm}$ long. Photograph by M.A. Wartes. 
and siltstone (fig. 17A); (2) light-gray- to gray-brown-weathering, channelized to tabular, locally cross-stratified, very-thickbedded, clast- to matrix-supported, amalgamated conglomerate and arkosic sandstone (fig. 17B and C); and (3) relatively recessive, dark-gray-weathering, tabular, thinner-bedded and finer-grained siltstone and subordinate arkosic sandstone (fig. 17D). A dearth of bioturbation in the lower Pomeroy was reported by Wartes and others (2013), but trace fossils were locally observed in the uppermost exposures of the Pomeroy along the Cook Inlet coast (fig. 17E). Wartes and others (2013) summarized recent lithostratigraphic work on the unit in Iniskin and Oil bays, interpreting the Oil Bay exposures of the lower Pomeroy as recording sediment-gravity-flow sedimentation. A map-scale thickness calculation for the Pomeroy Arkose Member in the Shark Tooth Hill area yielded an estimated minimum stratigraphic thickness of $899 \mathrm{~m}$ (fig. 2).

\section{SUMMARY AND FUTURE WORK}

The geologic mapping criteria and preliminary sketch map of the Tilted Hills presented here are largely consistent with published maps. However, new field observations and access by helicopter to the rugged high country of the Tilted Hills yielded additional insights into the Chinitna and Naknek Formations, including areas where mapping discrepancies had persisted. The Mount Pomeroy area is an example of a location where we clearly documented what had previously been somewhat enigmatic Chisik-lower sandstone and Snug Harbor-Pomeroy field relations. Interpreting these and other basinscale lithostratigraphic relations in the context of our growing inventory of measured stratigraphic sections and associated analytical results (DGGS, unpublished data) will serve as a basis for pending reports regarding sedimentation in the Cook Inlet forearc basin. This paper and related studies, including additional fieldwork planned for the area north of Chinitna Bay, will contribute to a better understanding of the basin's evolution during Middle and Late Jurassic time and the hydrocarbon potential of Mesozoic strata in the Cook Inlet region.

\section{ACKNOWLEDGMENTS}

Funding for this work was provided by the State of Alaska and the National Cooperative Geologic Mapping Program through STATEMAP under award number G13AC00157 (administered by the USGS). Cook Inlet Region, Inc. (CIRI), and Chickaloon, Knik, Ninilchik, Salamatof, Seldovia, and Tyonek village corporations permitted land access for this work on the Iniskin Peninsula.

We recognize and thank our DGGS, DOG, and USGS colleagues who took part in recent field campaigns in the Iniskin Peninsula area, including: Dave LePain, Rick Stanley, Bob Gillis, Paul Decker, Ken Helmold, Paul Betka, Bob Swenson, Kate Bull, and Shaun Peterson; countless discussions with these geologists yielded many insights into the Chinitna and Naknek Formations. Bekah Tsigonis (DGGS intern) performed many mundane office tasks with timeliness and precision.

Room and board during our field seasons on the Iniskin Peninsula were provided by James and Shelia Isaak of Alaska Homestead Lodge, the Williams family at Pile Bay, and the McGahan family and staff at Bear Mountain Lodge. Mike Fell and Melissa Elerick of Pathfinder Aviation supplied rotary-wing aircraft with skilled pilots; we thank helicopter pilots Merlin "Spanky" Handley, George Ticknor, and Roger Hinsdale, who safely deployed and collected our field crews daily, often during adverse weather conditions. Fixed-wing pilots Jack Barber, Jose de Creeft, and Trent Fluckey, among others, transported our field crews on many occasions and made numerous difficult landings in the challenging conditions of lower Cook Inlet.

Andrea Loveland reviewed an abbreviated version of this report, and Bob Gillis commented on an early draft of the manuscript. Thorough reviews by Rick Stanley and Dave LePain improved this paper. Paula Davis edited the manuscript and Joni Robinson provided the formatting and layout.

\section{REFERENCES CITED}

Betka, P.M., and Gillis, R.J., 2014, Preliminary kinematic evidence for right-lateral slip along a system of steeply-dipping faults located in the hanging wall of the Bruin Bay fault, Iniskin Peninsula, lower Cook Inlet, Alaska, in Gillis. R.J., ed., Cook Inlet program 2013 field studies - Observations and preliminary interpretations from new 1:63,360-scale geologic mapping of the Iniskin Peninsula, lower Cook Inlet, Alaska: Alaska Division of Geological \& Geophysical Surveys Preliminary Interpretive Report 2014-2-4, p. 17-22.

- in press, Preliminary characterization of brittle deformation on the Iniskin Peninsula-Implications for the kinematic history of the Bruin Bay fault system, lower Cook Inlet, Alaska: Alaska Division of Geological \& Geophysical Surveys Preliminary Interpretive Report.

Blasko, D.P., 1976, Oil and gas exploration on the Iniskin Peninsula, Alaska: U.S. Bureau of Mines Open-File Report 6976, 19 p.,http://www.dggs.alaska.gov/pubs/id/21439.

Callomon, J.H., 1984, A review of the biostratigraphy of the post-lower Bajocian Jurassic ammonites of western and northern North America, in Westermann, G.E.G., ed., Jurassic-Cretaceous biochronology and paleogeography of North America: Geological Association of Canada Special Paper 27, p. 143-174.

Compton, R.R., 1985, Geology in the Field: John Wiley and Sons, New York, 398 p. 
Detterman, R.L., and Hartsock, J.K., 1966, Geology of the Iniskin-Tuxedni region, Alaska: U.S. Geological Survey Professional Paper 512, 78 p., 6 sheets, scale 1:63,360, http://www.dggs.alaska.gov/pubs/id/3873.

Detterman, R.L., and Reed, B.L., 1980, Stratigraphy, structure, and economic geology of the Iliamna quadrangle, Alaska: U.S. Geological Survey Bulletin 1368-B, p. B1-B86, 1 sheet, scale 1:250,000, http://www.dggs.alaska.gov/pubs/id/3682.

Detterman, R.L., Case, J.E., Miller, J.W., Wilson, F.H., and Yount, M.E., 1996, Stratigraphic framework of the Alaska Peninsula: U.S. Geological Survey Bulletin 1969-A, 74 p., http://www.dggs.alaska.gov/webpubs/usgs/b/text/b1969a.pdf.

Gillis, R.J., ed., 2013, Overview of 2012 field studies - Upper Alaska Peninsula and west side of lower Cook Inlet, Alaska: Alaska Division of Geological \& Geophysical Surveys Preliminary Interpretive Report 2013-1, 7 chapters, 48 p., http:// www.dggs.alaska.gov/webpubs/dggs/pir/text/pir2013 001.pdf.

2014, Cook Inlet program 2013 field studies — Observations and preliminary interpretations from new 1:63,360-scale geologic mapping of the Iniskin Peninsula, lower Cook Inlet, Alaska: Alaska Division of Geological \& Geophysical Surveys Preliminary Interpretive Report 2014-2, 31 p.

Gillis, R.J., Swenson, R.F., Wartes, M.A., and Frohman, R.A., 2013, Reconnaissance investigations of the Bruin Bay fault system along the western margin of lower Cook Inlet and upper Alaska Peninsula, in Gillis, R.J., ed., Overview of 2012 field studies - Upper Alaska Peninsula and west side of lower Cook Inlet, Alaska: Alaska Division of Geological \& Geophysical Surveys Preliminary Interpretive Report 2013-1G, p. 33-37, http://www.dggs.alaska.gov/webpubs/dggs/ pir/text/pir2013 001g.pdf.

Gillis, R.J., Wartes, M.A., and O'Sullivan, P.B., 2011, Preliminary findings from reconnaissance structural studies along the Bruin Bay fault system and adjacent areas, south-central Alaska [abs.]: American Association of Petroleum Geologists, Pacific Section Annual Meeting, p. 58, http://www.searchand-discovery.com/abstracts/pdf/2011/pacific/abstracts/ ndx gillis.pdf.

Gillis, R.J., Wartes, M.A., Herriott, T.M., Bull, K., Decker, P.D., and Betka, P.M., 2014, Overview of new 1:63,360-scale geologic mapping of the Iniskin Peninsula, lower Cook Inlet, Alaska, in Gillis. R.J., ed., Cook Inlet program 2013 field studies - Observations and preliminary interpretations from new 1:63,360-scale geologic mapping of the Iniskin Peninsula, lower Cook Inlet, Alaska: Alaska Division of Geological \& Geophysical Surveys Preliminary Interpretive Report 2014-2-1, p. 3-6.

Gradstein, F.M., Ogg, J.G., Schmitz, M.D., and Ogg, G.M., eds., 2012, The Geologic Time Scale 2012: Elsevier, 2 volumes, 1,144 p., DOI: 10.1016/B978-0-444-59425-9.00004-4.

Hartsock, J.K., 1954, Geologic map and structure sections of the Iniskin Peninsula and adjacent area of Alaska: U.S. Geological Survey Open-File Report 54-118, 1 p., 3 sheets, http://www.dggs.alaska.gov/pubs/id/10502.

Herriott, T.M., and Wartes, M.A., 2014, Brief overview of geologic mapping of the Middle Jurassic Chinitna Formation and Upper Jurassic Naknek Formation in the Tilted Hills, Iniskin Peninsula, Cook Inlet, Alaska, in Gillis. R.J., ed., Cook Inlet program 2013 field studies - Observations and preliminary interpretations from new 1:63,360-scale geologic mapping of the Iniskin Peninsula, lower Cook Inlet, Alaska: Alaska Division of Geological \& Geophysical Surveys Preliminary Interpretive Report 2014-2-5, p. 23-28.

Imlay, R.W., 1953, Callovian (Jurassic) ammonites from the United States and Alaska; Part 2, Alaska Peninsula and Cook Inlet regions: U.S. Geological Survey Professional Paper 249-B, p. 41-108, 2 sheets, http://www.dggs.alaska.gov/ pubs/id/3815.

1975, Stratigraphic distribution and zonation of Jurassic (Callovian) ammonites in southern Alaska: U.S. Geological Survey Professional Paper 836, 28 p., http://www.dggs.alaska.gov/webpubs/usgs/p/text/p0836.pdf.

1981a, Jurassic (Bathonian and Callovian) ammonites in eastern Oregon and western Idaho: U.S. Geological Survey Professional Paper 1142, 24 p.

_ 1981b, Late Jurassic ammonites from Alaska: U.S. Geological Survey Professional Paper 1190, 40 p., http://www. dggs.alaska.gov/webpubs/usgs/p/text/p1190.pdf.

Kirschner, C.E., and Minard, D.L., 1949, Geology of the Iniskin Peninsula, Alaska: U.S. Geological Survey Oil and Gas Investigations Map 95, 1 sheet, scale 1:48,000, http://www.dggs.alaska.gov/webpubs/usgs/om/oversized/om095 sh001.pdf.

LePain, D.L., Stanley, R.G., Gillis, R.J., Helmold, K.P., Peterson, C.S., and Wartes, M.A., 2011, Deposition of Middle Jurassic Tuxedni Group, lower Cook Inlet, Alaska-Initial exhumation of an Early Jurassic island arc and incipient motion on the Bruin Bay fault zone [abs.]: American Association of Petroleum Geologists, Pacific Section Annual Meeting, p. 71, http://www.searchanddiscovery.com/abstracts/pdf/2011/pacific/abstracts/ndx le.pdf.

LePain, D.L., Stanley, R.G., Helmold, K.P., and Shellenbaum, D.P., 2013, Geologic framework and petroleum systems of Cook Inlet basin, south-central Alaska, in Stone, D.M., and Hite, D.M., eds., Oil and Gas Fields of the Cook Inlet Basin: American Association of Petroleum Geologists Memoir 104, p. 37-116.

Lillis, P.G., and Stanley, R.G., 2011, Petroleum generation modeling for Cook Inlet basin, Alaska [abs.]: American Association of Petroleum Geologists, Pacific Section Annual Meeting, p. 72. 
Magoon, L.B., 1994, Tuxedni-Hemlock(!) petroleum system in Cook Inlet, Alaska, U.S.A., in Magoon, L.B., and Dow, W.G., eds., The petroleum system-From source to trap: American Association of Petroleum Geologists Memoir 60, p. 359-370.

Magoon, L.B., Adkison, W.L., and Egbert, R.M., 1976, Map showing geology, wildcat wells, Tertiary plant fossil localities, K-Ar age dates, and petroleum operations, Cook Inlet area, Alaska: U.S. Geological Survey Miscellaneous Investigations Series Map 1019, 3 sheets, scale 1:250,000, http://www.dggs.alaska.gov/pubs/id/12849.

Magoon, L.B., and Anders, D.E., 1992, Oil-to-source-rock correlation using carbon-isotopic data and biological marker compounds, Cook Inlet—Alaska Peninsula, Alaska, in Moldowan, J.M., Albrecht, P., and Philp, R.P., eds., Biological markers in sediments and petroleum: Englewood Cliffs, N.J., Prentice-Hall, p. 241-274.

Martin, G.C., 1905, The petroleum fields of the Pacific coast of Alaska, with an account of the Bering River coal deposits: U.S. Geological Survey Bulletin 250, 64 p, http://www.dggs.alaska.gov/webpubs/usgs/b/text/b0250.pdf.

Martin, G.C., and Katz, F.J., 1912, A geologic reconnaissance of the Iliamna region, Alaska: U.S. Geological Survey Bulletin 485, 138 p., 2 sheets, scale 1:250,000, http://www.dggs.alaska.gov/pubs/id/3400.

Maubeuge, P.L., ed., 1964, Colloque du Jurassique à Luxembourg 1962: Luxembourg, Publication de l'Institut Grand-Ducal, Section des Sciences Naturelles, Physiques et Mathématiques, 948 p.

Moffit, F.H., 1927, The Iniskin-Chinitna Peninsula and the Snug Harbor district, Alaska: U.S. Geological Survey Bulletin 789, 71 p., 5 sheets, scale 1:250,000, http://www.dggs.alaska.gov/pubs/id/3440.

Spurr, J.E., 1900, A reconnaissance in southwestern Alaska in 1898: U.S. Geological Survey 20th Annual Report, part 7, p. 31-264.

Stanton, T.W., and Martin, G.C., 1905, Mesozoic section on Cook Inlet and Alaska Peninsula: Geological Society of America Bulletin, v. 16, p. 391-410.

Stanley, R.G., Herriott, T.M., LePain, D.L., Helmold, K.P., and Peterson, C.S., 2013, Reconnaissance studies of potential petroleum source rocks in the Middle Jurassic Tuxedni Group near Red Glacier, eastern slope of Iliamna Volcano, in Gillis, R.J., ed., Overview of 2012 field studies-Upper Alaska Peninsula and west side of lower Cook Inlet, Alaska: Alaska Division of Geological \& Geophysical Surveys Preliminary Interpretive Report 2013-1B, p. 5-9, http://dx.doi. org $/ 10.14509 / 24624$.

Wartes, M.A., and Herriott, T.M., 2014, Discovery of oil-stained sandstone within the Chinitna Formation, northern Iniskin Peninsula, in Gillis. R.J., ed., Cook Inlet program 2013 field studies-Observations and preliminary interpretations from new 1:63,360-scale geologic mapping of the Iniskin Peninsula, lower Cook Inlet, Alaska: Alaska Division of Geological \& Geophysical Surveys Preliminary Interpretive Report 2014-2-6, p. 29-31.

in press, Discovery of oil-stained sandstone within the Middle Jurassic lower Paveloff Siltstone Member of the Chinitna Formation, northern Iniskin Peninsula: Alaska Division of Geological \& Geophysical Surveys Preliminary Interpretive Report.

Wartes, M.A., Herriott, T.M., Helmold, K.P., Gillis, R.J., LePain, D.L., and Stanley, R.G., 2011, Stratigraphic evidence for Late Jurassic activity on the Bruin Bay fault, Iniskin Peninsula, lower Cook Inlet, Alaska [abs.]: American Association of Petroleum Geologists, Pacific Section Annual Meeting, p. 96-97, http://www.searchanddiscovery.com/abstracts/ pdf/2011/pacific/abstracts/ndx wartes02.pdf.

Wartes, M.A., Herriott, T.M., Helmold, K.P., and Gillis, R.J., 2013, Preliminary stratigraphic interpretation of the Naknek Formation-Evidence for Late Jurassic activity on the Bruin Bay fault, Iniskin Peninsula, lower Cook Inlet, in Gillis, R.J., ed., Overview of 2012 field studies - Upper Alaska Peninsula and west side of lower Cook Inlet, Alaska: Alaska Division of Geological \& Geophysical Surveys Preliminary Interpretive Report 2013-1H, p. 39-46, http://dx.doi. org/10.14509/24851.

Wilson, F.H., Dover, J.H., Bradley, D.C., Weber, F.R., Bundtzen, T.K., and Haeussler, P.J., 1998, Geologic map of central (Interior) Alaska: U.S. Geological Survey Open-File Report 98-133, 63 p., pamphlet, 13 p. appendix, 3 sheets, scale 1:500,000, http://pubs.usgs.gov/of/1998/of98-133-a/.

Wilson, F.H., Hults, C.P., Schmoll, H.R., Haeussler, P.J., Schmidt, J.M., Yehle, L.A., and Labay, K.A., 2012, Geologic map of the Cook Inlet region, Alaska, including parts of the Talkeetna, Talkeetna Mountains, Tyonek, Anchorage, Lake Clark, Kenai, Seward, Iliamna, Seldovia, Mount Katmai, and Afognak quadrangles: U.S. Geological Survey Scientific Investigations Map 3153, 76 p., 2 sheets, scale 1:250,000, http://www.dggs.alaska.gov/pubs/id/24604. 